\title{
Understanding the Service Infusion Process as a Business Model
}

\section{Reconfiguration}

\author{
Submitted for Review \\ Industrial Marketing Management
}

Special Issue on De-constructing the assumptions behind service-led growth in product firms: Deservitization, multiple strategic positions, mergers and acquisitions, industries and markets, and theoretical foundations

SI Editors Christian Kowalkowski, Heiko Gebauer and Rogelio Oliva

Original submission: September 2014

Revised submission: September 2015

Second revised submission: March 2016

Accepted for Publication: April 2016

Sebastian Forkmann* (corresponding author), Lecturer/Assistant Professor of Marketing and Supply Chain Management, Business Ecosystem Research Group, Queen Mary University of London, Mile End, London E14NS, United Kingdom, +44 (0)207 8826612 , s.forkmann@qmul.ac.uk.

Carla Ramos, Assistant Professor of Marketing, Insper, Rua Quatá 300, 04546-042, Vila Olímpia, São Paulo, Brasil, +55 11 (9) 75424161, carlasdmr@insper.edu.br.

Stephan C. Henneberg, Chair Professor of Marketing and Strategy, Business Ecosystem Research Group, Queen Mary University of London, Mile End, London E14NS, United Kingdom, +44 (0)207882 2706, s.henneberg@qmul.ac.uk.

Peter Naudé, Professor of Marketing, Manchester Business School, Booth Street West, Manchester M156PB, United Kingdom, +44 (0)161 2757782 , peter.naude@manchester.ac.uk and Discipline of Marketing, University of Sydney Business School, Sydney, Australia. 


\begin{abstract}
This study conceptualizes service infusion as a business model reconfiguration by using a process perspective. Service infusion is therefore understood as a process affecting the business model dimensions of transaction content, structure, and governance. The servicerelated reconfiguration of the business model is explained by underlying knowledge conversion mechanisms, which provide insights into the development of reconfiguration capacities as important enablers for business model change. Furthermore, this study introduces the concept of service defusion as an important counterpart to service infusion. Both concepts together are found to fully capture firms' strategic options with respect to their service offering components (transaction content), their engagement with, and disengagement from, important business partners (transaction structure), and also their interactions with these important business partners (transaction governance). The conceptually derived understanding of the service infusion process and mechanisms are exemplified via a multiactor longitudinal illustrative case study. A conceptual grounding for understanding service infusion processes for further theory and concept development is provided, and managers gain an understanding of how to effectively manage the processes underlying service-related business model reconfigurations.
\end{abstract}

\title{
Keywords
}

Service infusion; Service defusion; Business model reconfiguration; Process perspective, Knowledge conversion mechanisms 


\section{Understanding the Service Infusion Process as a Business Model Reconfiguration}

\section{Introduction}

Services are becoming increasingly important for firms competing in industrial markets (Ostrom et al., 2010; Ulaga \& Reinartz, 2011). Firms that traditionally produced goods are driven to reinvent themselves to stay competitive by developing their business models through services (Mathieu, 2001a, 2001b). This is due to a need to counter everquicker commoditization that threatens their product offerings and erodes their market position (Baines et al., 2009; Kowalkowski et al., 2012; Ostrom et al., 2010; Shankar et al., 2009). Such service infusion as a new business model option for manufacturers is argued to increase the value of their offerings (Baines et al., 2009; Frambach et al., 1997; Vandermerwe \& Rada, 1988). It thereby provides ways in which manufacturing firms can sustain their market position, increase their competitiveness and allow them to access promising new revenue streams (Baines et al., 2009; Gebauer \& Friedli, 2005; Johnson et al., 2008; Mathieu, 2001a, 2001b; Oliva \& Kallenberg, 2003). Several recent studies indicate the positive effects of service infusion strategies on firm performance, but they also caution that this is not an automatic effect (Eggert et al., 2011, 2014; Fang et al., 2008; Homburg et al., 2003; Neely,

2008). However, business environments are constantly changing and thus achieving competitiveness may require manufacturers to continuously adjust their offering composition, for example by reducing certain services while introducing new ones, or refocusing on the product-based components of their offering. Thus, manufacturing companies need to be able to increase but also to reduce the service content of their offering, i.e. they may engage in service defusion. From this perspective, service infusion and defusion allow manufacturers to react to changing business environments or to seize market opportunities through changing 
the service components of their business models (Anderson \& Narus, 1995; Kindström, 2010; Kowalkowski et al., 2012).

Research into service infusion has focused on providing manufacturers with guidance as to different strategies that they can adopt to venture into service provision (e.g. Gebauer, 2008; Gebauer et al., 2010; Löfberg et al., 2010; Raddats \& Easingwood, 2010). The literature focuses on aspects of organizational culture, structure, and the capabilities and resources that are necessary for service infusion (e.g. Bjurklo et al., 2009; Homburg et al., 2003; Neu \& Brown, 2005; Ulaga \& Reinartz, 2011) as well as the network context of service infusion (Nenonen \& Storbacka, 2010; Kowalkowski et al., 2013; Gebauer et al., 2013; Spring \& Araújo, 2013). However, the extant literature conceptualizes service infusion most often as the 'outcome' of a change in business models, not as the 'change process' itself. Thus, service infusion is seen as the end-result, in a static manner, while the dynamic aspect of the processes and mechanisms of how it is achieved, the service infusion process, remains largely under-researched (Baines et al., 2009; Steiner et al., 2014). Extant research on issues around service infusion processes focuses on aspects of the different process steps (Zeithaml et al., 2014; Oliva \& Kallenberg, 2003), the dynamic and emergent nature of these processes (Biggemann et al., 2013; Ferreira et al., 2012; Kowalkowski et al., 2012; 2013; Matthyssens \& Vandenbempt, 2008), or the impact of processes on service infusion success (Kowalkowski et al., 2015). However, process issues in the context of service infusion are usually not conceptualized around the reconfiguration of particular business model components. This represents a challenge, as practice needs guidance on how to implement service infusion as part of strategic changes, and theory depends on an understanding of the components and mechanisms underpinning the change process associated with service infusion as a business model in order to analyse aspects of performance or contextual factors associated with service infusion. We therefore focus in this article on the overarching 
research objective of understanding the service infusion process, which drives the development of service-infused business models.

Service infusion is built on the premise of creating and capturing additional value through services and as such presents an innovative business model. According to Amit and Zott (2001, p. 511), a firm's business model can be defined as "the content, structure, and governance of transactions designed so as to create value through the exploitation of business opportunities." Such a business model is centred around a particular firm, which 'owns' the business model and competes with other firms' business models on the basis of creating value for customers, and appropriation of value for the firm (Johnson et al., 2008). Business models, such as those providing service-infused offerings, are therefore a firm's specific response to certain business opportunities, are customer-focused and include the interactions with other relevant business partners within business networks (Amit \& Zott, 2001). We argue (as an extension to our research objective) that the process of service infusion corresponds to a business model reconfiguration, i.e. the firm's original business model structure and governance changes linked to the content-related changes as expressed in the service-infused offering.

To achieve a business model reconfiguration, firms need certain capabilities. Such change-oriented capabilities are defined by Teece and colleagues (1997) as a specific aspect of dynamic capabilities, in particular as reconfiguration capacities (Teece, 2007). These have previously been discussed as part of the research on service infusion (Kindström et al., 2013). We focus specifically on an understanding of the knowledge conversion mechanisms that take place during the service infusion processes, in particular creating, transforming, and exchanging knowledge (Nonaka \& Takeuchi, 1995). Knowledge is seen as a crucial resource in enabling changes, and thus underpins reconfiguration processes (Easterby-Smith \& Prieto, 
2008). It is therefore integral to understand the service infusion process, and informs part of our research.

The contributions of this article are fourfold. First, we provide a conceptual understanding of the processes underlying service infusion, and thereby inform the recent literature on process characteristics and in particularly the outcome-focused literature. This is important as achieving service infusion represents a considerable managerial challenge. Contingencies of achieving superior performance through service infusion are well documented and point to the importance of understanding mechanisms that drive the underlying process (Eggert et al., 2011, 2014; Fang et al., 2008; Homburg et al., 2003; Steiner et al., 2014). Secondly, we show the importance of knowledge, in particular knowledge creation, transformation, and exchange, for the service infusion process. This provides a micro-level perspective of the change mechanisms and enables insights as well as a conceptual foundation for research on the development of reconfiguration capacities in the context of service infusion. Thirdly, we introduce the concept of service defusion as a complementary service-related strategy for business model reconfiguration. This is important as it provides an understanding of alternative service strategies in industrial markets. Fourthly, the concept of service defusion provides the departure point for a systemic perspective for business model reconfiguration in which service infusion and defusion often represent antagonistic processes within an equilibrium of business model reconfiguration dimensions. This highlights additional mechanisms for business model reconfiguration from a services perspective.

Overall, our study adds to the literature on service infusion by adopting the concept of business model reconfiguration. As such, we use a conceptual foundation which utilizes a business model perspective (Amit \& Zott, 2001) on service infusion/defusion by linking the change (or reconfiguration) of such a business model to the underlying dynamic capabilities 
(Teece, 2010) which allow a firm to sense and seize such reconfigurations, in particular those related to the implementation and management of the change processes involved (Osterwalder, 2004; Zott et al., 2011). To understand these dynamic capabilities, we employ a knowledge-based perspective, in particular the knowledge conversion processes involved in service infusion (Nonaka, 1994; Ernst \& Kim, 2002), and link them with reconfiguration capacities (Teece, 2007).

The remainder of the article is structured as follows. In order to provide a theoretical grounding, we first introduce service infusion using the concept of the business model. Focussing on the process to achieve service-infused offerings, we discuss this as a business model reconfiguration, before we describe the knowledge conversion underlying service infusion processes. This is followed by an in-depth analysis of an illustrative multi-actor case study, which provides a dynamic description of the service infusion and defusion processes over time as part of the business model reconfiguration of a Northern European manufacturer of automated warehouse systems. The exemplifying and illustrative case study solidifies the conceptual framework developed on the process of service infusion as a business model reconfiguration, as well as provides examples of the underlying knowledge conversion mechanisms. Finally, we provide a discussion of the insights gained from our conceptualization and empirical exemplification of the service infusion and defusion processes, outline theoretical and managerial implications, and identify limitations and possible further research related to our study.

\section{Theoretical Framework}

\subsection{Service Infusion as a Business Model}

Service infusion (Brax, 2005; Eggert et al., 2011; Kowalkowski et al., 2012), also known in the literature as servitization (Vandermerwe \& Rada, 1988) or product-service 
systems (Barquet et al., 2013), refers to a strategic shift in firms' offerings from "traditional core product business [to] developing ancillary service offerings and value-added solutions" (Eggert et al., 2011, p. 661). According to Oliva and Kallenberg (2003), the transition follows a continuum with increasing degrees of services added to the total offering of a manufacturing firm, coupled with higher integration of services and products (Vandermerwe \& Rada, 1988), and more complete offerings (Penttinen \& Palmer, 2007). Kowalkowski et al. (2012) argue that rather than a unidirectional transition taken in a few large steps, service infusion evolves incrementally and without clear direction. Thus, from their perspective, service infusion is an emergent strategy, based on intermittent processes driven by firms' fast-paced changing business environments (Kowalkowski et al., 2015).

Service infusion, in particular in industries characterized by increasing commoditization and accelerating product life-cycles, allows firms to achieve competitive advantage through service differentiation (Frambach et al., 1997; Mathieu, 2001a; Matthyssens \& Vandenbempt, 2008). Manufacturers consider venturing into business services as these generally promise higher profit margins and provide more stable cash flows than products, which often follow economic cycles and are thus less predictable (Davies, 2004; Eggert et al., 2011; Frambach et al., 1997; Mathieu, 2001a). In addition, business customers are increasingly demanding product-related services and generally more complete offerings, and manufacturers have found that enhancing product offerings with services positively influences the purchasing decision and thereby helps to increase product sales (Frambach et al., 1997; Mathieu, 2001a; Oliva \& Kallenberg, 2003). Service infusion facilitates competition with other firms' business models on the basis of creating and appropriating value (Johnson et al., 2008). Therefore, in order to address the process of achieving service infusion, the phenomenon is understood as being embedded in the overall business model of a firm (Barquet et al., 2013). 
According to Amit and Zott's (2001) definition, business models represent how a firm intends to compete in a market, and can be conceptualized along three dimensions: 1) transaction content, 2) transaction structure, and 3) transaction governance. While transaction content refers to the bundle of goods, services, and information exchanged, and the associated resources and capabilities necessary to facilitate these exchanges (Fang et al., 2008; Steiner et al., 2014; Stremersch et al., 2001), transaction structure refers to the actors involved in the exchange and the way they are interlinked. Finally, transaction governance describes the governance mechanisms in place that control the flow of goods, services, resources and information as part of the inter-organizational transactions.

Different frameworks exist that guide manufacturers' service infusion. Mathieu (2001b) distinguishes between services supporting the product (SSPs) and services supporting the customer (SSCs), with the latter requiring close customer relationships, customization, and adaptation. As firms move further up the product-service continuum, the product and service components become less separated from each other. The resulting offerings are referred to as hybrids (Ulaga \& Reinartz, 2011), bundles (Stremersch \& Tellis, 2002), full services (Stremersch et al., 2001), systems (Mattsson, 1973), and integrated or customer solutions (Brax \& Jonsson, 2008; Davies, 2004; Nordin \& Kowalkowski, 2010; Storbacka, 2011; Tuli et al., 2007). Service infusion therefore spans a wide range of forms, from adding basic SSPs to augment the traditional product offering (Frambach et al., 1997), through to major shifts of manufacturing firms to become integrated solution providers (Davies, 2004; Matthyssens \& Vandenbempt, 2008; Windahl \& Lakemond, 2006), or even business service organizations (Oliva \& Kallenberg, 2003).

In order to achieve such a content-related business model change, the other dimensions, i.e. structure and governance, are also affected. The literature recognizes that moving along the product-service continuum requires firms to build and manage closer 
customer relationships and provide increasingly customized offerings (e.g. Kindström, 2010; Mathyssens \& Vandenbempt, 1998; Penttinen \& Palmer, 2007; Tuli et al., 2007; Wise \& Baumgartner, 1999). While closer relationships offer many opportunities, they also require sets of relational capabilities that typically go beyond that of traditional product-focused manufacturers (Kindström \& Kowalkowski, 2009). Furthermore, value creation through service infusion involves multiple actors, such as customers, distributors, suppliers, development partners, third party service providers, and others (Cova \& Salle, 2008; Kowalkowski et al., 2013; Windahl \& Lakemond, 2006). As many manufacturers venturing into services do not have prior experience or expertise of service infusion, such networks of relationships offer access to the requisite resources and capabilities (Cantú et al., 2011; Jaakkola \& Hakanen, 2012; Mathieu, 2001a). As a consequence, service infusion can be understood as a network phenomenon. Thus, from a business model perspective, structure is affected through the network characteristics of service infusion and governance through the management of the associated relationships. As a consequence, the process of service infusion involves changes in all three business model dimensions, i.e. content, structure, and governance and represents a business model reconfiguration.

\subsection{Service Infusion Process as a Business Model Reconfiguration}

While business models represent a snapshot at a specific point in time, firms have to continuously reconfigure their business models in order to stay competitive (Teece, 2010). Understanding such business model changes has received increasing attention (Calia et al., 2007; Osterwalder, 2004). Teece (2010) talks in this context about business model reshaping, adjusting, redefinition, and adaptation of configuration. Business model changes are also

referred to in the literature as business model innovation (Chesbrough, 2010; Gambardella \& McGahan, 2010; Zott et al., 2011), evolution or reformulation (Morris et al., 2005), redesign (Osterwalder, 2004), dynamism (Mason \& Leek, 2008; Ferreira et al., 2013), renewal or 
reconfiguration (Chesbrough, 2010; Sandstrom \& Osborne, 2011). We refer to it in the context of our argument as business model reconfiguration, which can take form through changes in various dimensions of the business model (Osterwalder, 2004). Due to the interdependence of the dimensions, changes in one have often consequences for the others (Zott et al., 2011).

We argue that service infusion as an innovative business model requires a change process and that this can be understood using a business model reconfiguration perspective with a systemic and longer-term focus on the three business model dimensions of content, structure, and governance (Wirtz et al., 2016). The service infusion process affects the transaction content of the business model by, for example, adding product-related services, or by integrating services and goods into new solutions. Because service infusion processes are often a network phenomenon, additional actors such as suppliers, distributors, or third party service providers can become involved as part of the infusion and therefore change the actor structure of the business model. This is captured via the transaction structure dimension. Both transaction content and structure can change independently of each other, so that content changes do not necessarily affect the structural level of the network (e.g. a supplying firm may add maintenance services) and vice versa (e.g. a service provided that relates to a core product or application, such as fleet management offered by a forklift truck manufacturer, may at some point be outsourced to a specialist service provider). However, transaction content and structure often vary together, so that the process of service infusion can happen along both the content level (the product-service continuum), and on the structural level (the business actors involved) (see figure 1). Thus, novel services (i.e. those that are new to the business model) can be infused by including new service providers, resulting in a new actor structure. Any shifts in transaction content or the structure of the business model in turn require adaptations of the underlying governance structure, i.e. 
coordination and monitoring mechanisms to ensure all actors involved in the final offering are in harmony. For example, transaction content-related shifts, namely shifts on the productservice continuum towards higher service content and integration, such as SSCs, require more relational involvement, adaptation and collaboration between the firms involved and the customers (Tuli et al., 2007). Alternatively, shifts in the transaction structure of the business model by involving a third party acting as a service provider for the manufacturer, or as an independent outsourcing provider, also affect the governance level. For example involving distributors as part of the business model requires different sets of governance mechanisms compared to a model based on a direct sales channel.

\section{Insert Figure 1 about here}

\subsection{A Systemic Perspective of Service Infusion Processes: The Issue of Defusion}

Business model reconfiguration is important for firms as they need to be able to continuously sense and react to opportunities and threats in order to stay competitive (Teece, 2010). However, the concept of service infusion, which is often interpreted as implying a unidirectional path up the product-service continuum, by itself falls short of fully capturing the relevant business model reconfiguration. A counterpart to the concept of service infusion is needed, which captures situations where firms decide to discontinue certain services, disintegrating or de-bundling certain solutions as reactions to their changing environment. This represents a de-bundling of the offering (Arzaghi et al., 2012; Kowalkowski et al., 2012, Stremersch et al., 2001). We put forward the concept of service defusion for this process ${ }^{1}$. Similar to service infusion, service defusion is not limited to a reconfiguration of the content level (a reduction in the service component of the overall offering of the manufacturer), but includes the structural and governance levels of the business model as well.

\footnotetext{
${ }^{1}$ As service infusion and servitization can be used as interchangeable terms, service defusion would therefore equate to a de-servitization.
} 
From this perspective, reallocations of services within a network, as in the case of service infusion, can constitute at the same time a service defusion process somewhere else in the network. In other words, a reallocation of services within the network may first require the defusion of the respective service in one part of the network, before it can be infused, or reallocated, in another part. For example, a manufacturing company that adds maintenance services to its core product offering (a SSC-based service infusion) represents only one aspect of the overall changes. Customers of this firm would have had to engage in maintenance activities of some kind all along; they may have done these themselves, or used third party specialists to do them. With the manufacturer now offering such infused service offerings together with their core products, customers who buy these in fact defuse this service, i.e. they do not engage in it themselves anymore, nor do they mobilize external partners to do so.

Figure 2 illustrates the overall framework of infusion and defusion processes. In line with the business model perspective, we arrive at a systemic picture of service infusion/defusion processes by examining the reconfigured transaction content, structure, and governance (Zott et al., 2011). From this perspective, a service infusion process along the structural level can be accompanied either by a service defusion process on the same level (line a; the service provision of an existing service within the business model is shifted to a new service provider) or by a service infusion process on the content level (line b; a new service is introduced to the business model with the help of a new service provider). Alternatively, a service defusion process along the structural level could mirror an infusion process on the same level (line a) as well as represent a defusion process on the content level (line c; the service provision of an existing service is removed from the business model). These possibilities of simultaneous infusion and defusion processes in the network also affect the governance mechanisms of all actors involved. Such a perspective assumes that within business systems or business groups, an equilibrium is maintained (Halinen et al., 1999; 
Smangs, 2006): if one part of the system is affected (e.g. by a manufacturer deciding to add business services to its offering), there exists the possibility of an impact on another part of the network, keeping the system in equilibrium (e.g. a customer company reducing its service activities). Even in cases where we consider the infusion process of novel services on a content level (i.e. business services which were not previously done internally by the customer or a third party), a systemic view presupposing an equilibrium of service infusion and defusion processes could be invoked: with every new service that an actor introduces, the hypothetical 'option' to offer this service by another network actor would 'expire' (line d). Thus, if at some point another actor were to infuse the same service, it would need to be defused from the actor that originally had infused it, which would then represent a service defusion process on the structural level (line a). Similarly, the defusion of a service from the content level of the business model would create the hypothetical option to infuse this service by another actor within the network (line d).

Insert Figure 2 about here

\subsection{Knowledge as an Enabler of the Service Infusion Process}

Achieving business model reconfiguration is not an easy task, and firms face multiple challenges to implement changes to their business models (Chesbrough, 2010). In particular, it requires specific dynamic capabilities, namely those of learning, staying flexible, experimenting and adjusting to new business logics (Chesbrough, 2010; Teece, 2010). We follow Teece (2007) and focus on dynamic capabilities, in particular reconfiguration capacities, which enable the business model change process. A crucial resource underpinning these reconfiguration capacities is knowledge (Easterby-Smith \& Prieto, 2008), which is important because of the interplay between content offering changes and the involvement of multiple actors on the structural level. In line with Nonaka and Takeuchi (1995) we focus on 
the conversion mechanisms of creation, transformation, and exchange of knowledge as exemplifying crucial mechanisms requiring reconfiguration capacities.

On the content level, the infusion process of novel services requires the actors involved to create new relevant knowledge and expertise associated with these activities (see figure 3). On the other hand, when pre-existing services are reallocated to new service providers, the primary focus is on knowledge exchange. Thus, on a structural level, actors defusing certain services may need to support those actors that subsequently infuse them, as the defusing actor has built up knowledge and capabilities relating to these services, which the infusing actor may lack. The redistribution of services in the network creates the need to establish a support structure between the infusing and defusing actors to facilitate knowledge exchange between them. Past research has found that knowledge creation and exchange are affected, amongst other factors, by the characteristics of knowledge, such as its complexity, ambiguity, or tacitness, (Grant, 1996; Simonin, 1999; Szulanski, 1996; Zander \& Kogut, 1995). Therefore, exchanging knowledge may first require its transformation into an exchangeable form. Managing this knowledge creation, transformation, and exchange among actors is a critical capacity for the business model reconfiguration (Teece, 2007).

\section{Insert Figure 3 about here}

In order to understand knowledge conversion, the literature makes an important distinction between tacit and explicit knowledge as these substantially affect the creation and exchange process (Nonaka, 1994; Polanyi, 1966). According to Ernst and Kim (2002, p. 1423), "explicit knowledge refers to knowledge that is codified in formal, systematic language (encoded knowledge). It is knowledge that can be combined, stored, retrieved, and transmitted with relative ease and through various mechanisms". On the other hand, tacit knowledge "is hard to codify and communicate" and "can only be expressed through action, 
commitment, and involvement in a specific context and locality. Tacit knowledge is based on experience: people acquire it through observation, imitation, and practice."

The creation and exchange of knowledge among actors is achieved either through conversion from tacit-to-tacit knowledge, i.e. socialization, or from explicit-to-explicit knowledge, i.e. combining (Nonaka, 1994). Socialization requires close interaction of the parties involved. Tacit knowledge is often difficult to codify, and therefore the receiver learns through observation, training and application under the guidance of the sender. The creation of novel tacit knowledge can also be achieved through socialization by means of joint development projects and mixed work groups (Blumenberg et al., 2009). Explicit knowledge on the other hand can be easily exchanged and, according to Nonaka (1994), new explicit knowledge is created though combining different pieces of explicit knowledge held by the actors involved. Explicit knowledge can be codified and exchanged, for example in the form of documents, blueprints, manuals, decision support systems, project management software, service level agreements, and contracts (Easterby-Smith et al., 2008; Blumenberg et al., 2009; Ernst \& Kim, 2002; Zollo \& Winter, 2002). However, such creation and exchange of knowledge is related to further knowledge conversion mechanisms. For example, the utilization of explicit knowledge exchanged or created through combining is contingent on an internalization of the knowledge and thus transition into the tacit knowledge base of actors involved (Nonaka, 1994). In this case, explicit knowledge is exchanged (i.e. combined), and through its application (i.e. internalization) broadens, extends, and reframes the original tacit knowledge base (Ernst \& Kim, 2002). Furthermore, in order to enable combining, tacit knowledge needs to be articulated in its explicit form through externalization (Ernst \& Kim, 2002). For the creation and exchange of knowledge both tacit and explicit knowledge conversion mechanisms are utilized simultaneously (Nonaka, 1996). 
Deploying procedures and routines aimed at facilitating the knowledge conversion mechanisms involved constitutes a reconfiguration capacity enabling the service infusion and defusion process (Teece, 2007). Therefore, understanding the interplay between business model dimensions on the one hand and the associated knowledge conversion mechanisms on the other allows for more fine-grained insights into the service infusion/defusion processes and in turn guides the development of reconfiguration capacities.

\section{Dynamic Service Business Model Case: Service Infusion and Defusion Processes}

\subsection{Focal case company and business model reconfiguration}

We conducted a retrospective, longitudinal and illustrative in-depth case study of a multi-actor service infusion and defusion process (Yin, 1994). This research design was chosen in order to exemplify and investigate the concept of service infusion and defusion processes as well as understand the critical knowledge conversion mechanisms that underlie these processes (Hartley, 2004). An in-depth case study has frequently been argued to be the appropriate way to explore and deepen our understanding of a novel area of research, and to solidify initial conceptual considerations (Ryals \& Humphries, 2007; Inkpen, 2008). The same has been observed for the adoption of a longitudinal or retrospective longitudinal approach (Koza \& Lewin, 1999; Glick et al., 1990). Furthermore, longitudinal case study research is particularly suitable for process-related research answering the resulting 'how'type questions (Langley, 1999; Stake, 2000; Yin, 1994) that can only be understood by looking into context-specific developments occurring over a period of time (Eisenhardt \& Bourgeois, 1988; Yin, 1994). Thus, processes and the underlying mechanisms of service infusion/defusion constitute the unit of analysis for our research (Punch, 1998; Yin, 1993, 1994), which correspond with reconfigurations of the business model and the knowledge conversion mechanisms. 
The context of our case was that of a focal product-oriented firm and the reconfiguration of its business model over a period of time. Our specific focus relates to the associated service infusion and defusion processes. The focal firm is a Northern European manufacturer of an automated warehouse system ${ }^{2}$. The company's core offering involves sophisticated robotic technology and comprises both tangible and software elements. The business model reconfiguration was triggered by the focal firm as part of a strategy towards an accelerated growth phase. This involved other connected actors, such as distributor and customer firms. The firm changed from having very few, close customer relationships (during the initial commercialization of the automated warehouse offering), to having a substantial customer base, as well as a distribution network through which it channels all product sales, service provisions, and customer relationship management. While the initial business model was based on close customer relationships to aid the development and honing of the offering via service infusion processes, the subsequent changes of the business model were driven by growth opportunities and resource limitations, resulting in service defusion processes. In particular, utilizing the market position of distributors, the focal firm was able to remain slim and agile while allowing rapid expansion across Europe, Asia and North America within a short period of time.

An initial analysis of press coverage and of the company's website, combined with five exploratory, informal interviews with representatives of the focal firm at an international trade fair (mainly sales and business development managers), led us to identify this case as suitable for our purposes. These preliminary discussions allowed us to gain an overview of the case and to begin mapping, through a snow-balling technique (Hartley, 2004; Ritchie \& Lewis, 2003), the main external firms involved in the focal firm's business model reconfiguration.

\footnotetext{
${ }^{2}$ The identity of all firms involved is kept anonymous for confidentiality reasons.
} 
This specific case was selected for its intrinsic features of deep and continuous data access, in combination with typifying a sustained business model reconfiguration case. As such, the case does not represent an extreme context, unique situation or deviant nature (Mason, 1996; Yin, 1994). This purposive sampling (Denzin \& Lincoln, 2000; Silverman, 2000) supports our aim of exemplifying our conceptual reasoning through a typical case. Typical case sampling is a purposive sampling technique used when one is interested in selecting a 'normal' case that corresponds to a profile of what is agreed as 'average', as it can be used as illustrative to other similar samples (Silverman, 2000). For the purpose of our study, we selected a typical case of service infusion relating to an example of business model reconfiguration. The selected multi-actor case is therefore instrumental (Stake, 2000), as it illustrates how service infusion and defusion processes underpin a business model reconfiguration, and thereby provides a detailed analysis of the underlying knowledge conversion mechanisms. It also helps to solidify our conceptual framework.

\subsection{Data collection and analysis}

Data collection from the focal firm as well as its main distributors and customers took place during 2012, covering the period between 2008 and mid-2012. This specific timeframe was selected as it enveloped the business model reconfiguration period of the focal firm. Primary data was collected via multiple semi-structured telephone and face-to-face interviews with managers from all firms included in the network (see appendix for illustrative key questions from the interview guide). The sampling was intentional and purposeful, and thus as part of data collection and analysis, further interview needs were identified and several waves of interviews took place with the aim of capturing a holistic representation of the case. This reflects the iterative process between data collection and data analysis that took place (Strauss \& Corbin, 1990). 
In total, eighteen interviews were conducted. Some respondents were interviewed on multiple occasions. Interviewees occupied diverse positions within their firms: in the focal company, we interviewed the company's founder, marketing manager, sales manager and software engineer. At the company's main distributors, we spoke with sales and product managers; and finally, interviews with customer firms included managers of the central warehouse, logistics, and IT departments, and also chief operating officers and warehouse managers (see table 1). All respondents were very knowledgeable and involved with the focal firm's product or services on a daily basis (for example, the Product Manager of the main distributor held primary responsibility for the focal firm's product in his company). Therefore, all interviewees were involved in the business model reconfiguration processes. The diversity of positions and viewpoints of our respondents allowed us to capture different and cumulatively complete perspectives of the research phenomenon (Dubois \& Araujo, 2007; Hartley, 2004). Thus, a triangulation process underpins our findings (Eisenhardt, 1989; Jick, 1979), an aspect of particular importance in retrospective research approaches where informants may lack clarity or detail in retrieving information about historical events (Huber \& Power, 1985).

Insert Table 1 about here

All interviews were recorded and transcribed verbatim. Interviews lasted on average between 60 and 90 minutes, and all were conducted in English (all respondents were highly proficient in the language). Secondary data was collected mainly from institutional reports, firm websites, strategy documents, and press coverage, with the aim of getting a more complete view of the situation, as well as to triangulate and validate the interview data (Yin, 1994; Stake, 2000). For instance, we observed major industry fair presentations by the focal company as well as participated in demonstrations detailing the functioning of sales and 
monitoring tools. The data collection process was ended when 'theoretical saturation' was reached (Buchanan et al., 1988; Strauss \& Corbin, 1990), i.e., “...no additional data [was] being found whereby the [researcher could] develop properties of the categor[ies]." (Glaser \& Strauss, 1967, p. 65). This means that later interviews that were conducted and analysed started to corroborate earlier interviews and therefore did contributed only marginally to gaining additional insights.

All collected data was content analysed (Gray, 2004; Ritchie \& Lewis, 2003). The coding and analysis was related to the core concepts of business model reconfiguration (i.e. transaction structure, transaction content and transaction governance) and the underlying knowledge conversion mechanisms (i.e. socialization, combination, internalization and externalization). The data analysis was therefore informed by the conceptual dimensions and mechanisms related to service infusion and defusion processes, thereby assuring construct validity and providing important insights relevant to the phenomenon of interest (Dubois \& Gibbert, 2010; Eisenhardt, 1989). Through the juxtaposition of concepts and data as part of the analysis, an abductive approach was followed (Dubois \& Gadde, 2002; Robson, 2002). Inter-rater reliability was tested (i.e. more than one researcher analysed the same set of data, which was followed by a juxtaposing of the different analyses results), and the resulting replicability of findings assured the reliability of the analysis (Brito, 1999; Krippendorff, 2004). The main findings were summarized and sent to the respondents in order to further validate the research. A few suggested changes resulted from this process, which also contributed to the study's validity (Gibbert et al., 2008; Yin, 1994).

\subsection{Case findings: service infusion and defusion processes}


3.3.1. The beacon customer phase: business model re-configuration I through focal firm service infusion processes

In 2008, after several years of development and in-house testing, the focal firm sold and installed their first automated warehouse system to a Northern European electronic components company. This beacon customer perceived new value in this core offering, agreeing to be a pilot-customer, in effect functioning as a laboratory and test center for further system development. This required a close and cooperative relationship, with high levels of commitment and communication across all hierarchical levels between the two parties, as illustrated by the following quote:

"I would think we have more communication with [focal firm] than absolutely necessary, and the reason is that I think we are eager to help each other to really make this work. So I don't mind us using a little more time than actually necessary just to take it another step to make this system improving and to be better... it is a very open relationship, we have discussions and we contact with all the way from the owners and top management to the guys on the floor." (Beacon customer firm)

The focal firm provided their customer with the latest upgrades, with the customer feeding back information on how to improve the system. In parallel, the focal firm started to involve the future distributor it had selected for selling the system to new customers. At this phase, the involvement of the distributor had two main purposes: providing support to the focal firm in planning and integrating the automated warehouse in the existing warehouse of the customer, and learning how to install and service the system. While the main expertise of the focal firm concerned the product and software features of the system, the distributor's competencies centred on planning the overall warehouse infrastructure at the customer in which the system would be integrated (Distributor firm quote: “... we have the process knowledge and [focal firm] has the technical knowledge about the system."). The actual 
independent service provision of the distributor to the beacon customer was minimal during this stage, as most of the planning and integration work performed by the distributor was still mediated by the focal firm.

On the content level of this initial business model, in addition to planning and installing the system at the customer site, and integrating it into the existing warehouse of the customer both physically and in terms of software, the primary services surrounding the system that needed to be performed for the customer were: spare part delivery, maintenance and repair services on the physical elements of the solution, upgrades, optimization and trouble shooting on the software elements, as well as training for the customer on the system and the individual components. At that time most of these services were novel to the business model of the focal firm and had to first be developed and subsequently infused into the relationship with the customer. Most of these services can be characterized as product-related services (SSPs); however, some optimization services showed aspects of customer-related service provision (SSCs) and therefore resemble a hybrid offering (Mathieu, 2001b).

With respect to the structural and governance levels of the initial business model, the focal firm planned from the outset that it would eventually establish a distributor network to facilitate growth. Initially the direct and close relationship between the focal firm and the beacon customer (without an intermediate distributor) was essential for the purpose of further developing the system, as well as building-up, codifying, and exchanging the relevant knowledge of how to install, integrate, and service the system at a customer's site. On the other hand, the desired business model of the focal firm was always aimed at minimizing the direct interactions (including those that related to service provisions) between the focal firm and the end customers. Thus, distributors were eventually supposed to take over fully all aspects of customer acquisition, installation, and service provision in the future (Focal firm quote: "We really believe that the only way to reach our targets to be a big international 
player in this area is to work with distributors, otherwise we would have to employ far too many people."). Depending on the distributor, the focal firm's system would be sold by the distributor as a sub-system integrated into larger warehouse solutions involving, for example, conveyor systems or other auxiliary components. Distributors would then also provide warehouse management software to control the overall system, as well as consulting services to optimize the overall warehouse installation.

As most of the relevant services did not exist at the beginning, they had to be developed and infused as part of the initial re-configuration stage. In knowledge terms, this was very much a situation of exchanging and jointly creating knowledge through tacit-to-tacit mechanisms (socialization) among the focal firm, the customer, and the distributor (Focal firm quote: "to be honest, we did not know too much and so we had to be involved at every level in the beginning."). The previous experiences of all firms involved with respect to the warehouse system in a real practical environment were minimal, and a lot of relevant knowledge had to be created jointly. As the focal firm had most expertise with respect to the actual hard- and software aspects of the system, it was leading the joint work on knowledge creation, with each of the other two parties contributing their relevant competencies and experiences. For example, the focal firm relied strongly on the distributor to help plan the overall warehouse footprint and integrate the focal firm's system. Nonetheless, due to a lack of expertise with the new system, the distributor also relied heavily on guidance from the focal firm to enable them to do this. At that time, most of the knowledge of the focal firm was tacit and not codified; it was exchanged with other actors by involving them in all relevant stages from planning, installing, integrating, optimizing and ultimately servicing the system. The primary knowledge creation and exchange mechanisms were tacit-to-tacit in this phase with the focal firm, the beacon customer, and the distributor building a community-ofpractice (Brown \& Duguid, 1991). Soon the focal firm started to use the experiences gained 
with the beacon customer to codify some of the knowledge into manuals, training processes, documents, service guidelines, contracts, and other support systems (externalization). This, in turn, enabled initial explicit knowledge exchange (combination and internalization) with the other parties, and thus reduced some of the transaction costs associated with the tacit-to-tacit knowledge exchanges. However, as will be seen later, the tacit-to-tacit knowledge exchange mechanisms remained important even throughout the second reconfiguration phase of the business model, i.e. the service defusion by the focal firm.

Figure 4 represents the structural and content aspects of the initial business model reconfiguration regarding the beacon customer phase. There exists a direct relationship between the focal firm and the customer, with the former having the lead on most of the service infusion activities developed and provided to the customer (see figure 4, arrow 1). On the other hand the relationships between the focal firm and the distributor and between the distributor and the customer were initially virtually dormant (see figure 4, dashed arrows). The interactions between the distributor and focal firm were primarily characterized by knowledge creation and exchange. In this phase service infusion primarily concerned the content level of the business model of the focal firm in the relationship with its customer.

\section{Insert Figure 4 about here}

3.3.2. The distributor development phase: business model re-configuration II through focal firm service defusion processes

In order to achieve the desired business model of the focal firm, i.e. a situation where all relevant business services are provided by the distributors in their relationships with customers, the relationship between the focal firm and the customer companies needed to be defused, while the relationships between the distributors and the customers needed to be infused along the entire service spectrum. This constitutes a shift in both the content and structural level of the business model. The focal firm service defusion and resulting infusion 
processes constitute a development towards the intended reconfigured business model of the focal company, and required considerable support and knowledge exchange between the defusing and the infusing actors. This business model reconfiguration II is depicted in figure 5. The distributor increasingly took over the service provision activities aimed at the customer (see figure 5: arrow 1b), so that the distributor-customer relationship became service infused. However, the focal firm remained partly involved in these interactions with the customer to support the distributor during the reconfiguration of the business model (see figure 5: arrow 1a), i.e. the relationship became partially service defused.

In order to accomplish the defusion and infusion of the different relationships between the relevant actors in the network, additional services to support the distributor with its service provision needed to be infused in the relationship between the focal firm and the distributor (figure 5, arrow 2). Those infusion activities related primarily to novel services that the focal firm developed to serve two main goals: to support the distributors' interaction with the customer, and to facilitate knowledge exchange with the distributor. The focal firm invested extensive resources into developing manuals as well as training (sales, installation, service, etc.) for its distributors (Focal firm quote: "We have all the competencies in-house ... so that we can really make some training material and train people because we have the competencies here all the time."). At some point during that phase, about $25 \%$ of the focal firm's workforce were engaged in these service infusion activities with the distributor. As the warehouse system was continuously under development, both manuals and training needed to be constantly updated. The focal firm first had to document any changes/upgrades being made, then announce these in a release plan well in advance of when they would become effective, and, finally, to synchronize distributor training schedules with the release plan in terms of timing as well as content. This process represents knowledge exchange by codification of tacit knowledge into manuals and training programmes, and thus into explicit 
knowledge (externalization), which is exchanged and internalized through its application, and thus enters the tacit knowledge base of the distributor.

The focal firm also continuously supported the distributors with a new account management team dedicated to each distributor, as well as 24/7 technical support, on which the distributors could rely when additional help was needed. This occurred primarily as customers acquired more and more knowledge about the system themselves in the process of using it. Thus, through tacit knowledge creation, customers learned to perform the basic services, as well as repairs and troubleshooting independently. Over time they acquired knowledge levels that were similar to, or even more advanced than, those of the distributors, who typically did not develop in-depth knowledge of installed and fully operational systems (Customer firm quote: "[Distributor] are not kind of living with the installation on a daily basis. ... my feeling is that our own people have more in-depth knowledge of what the operation is all about than the installation guys from [Distributor]"). Service requests by customers that required outside help became more specific and advanced over time during this phase, which presented a challenge to the distributors if they were not able to achieve a comparable level of expertise to the customer. However, if a distributor required help from the focal firm for a specific customer problem, the two parties interacted closely in seeking a resolution, in the hope that the distributor would be able to address similar issues independently in the future (Focal firm quote: "What we are normally doing is that we are sending people down to solve the issues at the customer site. And the agreement is that the distributor at the same time will have their people there to learn what we are doing."). This constitutes another tacit-to-tacit knowledge exchange mechanism (socialization) and is particularly important as not all knowledge can be codified and exchanged in an explicit format through manuals and training routines. Thus, tacit-to-tacit knowledge exchange mechanisms remained important throughout the second reconfiguration phase of the business 
model (Distributor firm quote: "[Focal firm and distributor] have exchanged and developed ideas together. [Focal firm] can't distance themselves too much.")

Furthermore, the focal firm developed several support tools to help the distributor during sales, installation, and servicing of the system. One of these was a computer simulation that allowed the user (i.e. distributor) to design the system and determine both the scope of supply (i.e. physical components of the system) and the optimal configuration for the system, while also verifying and monitoring the actual performance of the installed system. Due to its comprehensive nature, this tool supported the distributors in the sales, installation, and after-sales phases. Distributors could use the simulation tool to develop business cases for prospective customers in the sales process (Distributor firm quote: "that means that there will be less involvement from [focal firm] in the pre-sales, because we can do all the pre-sales simulations and design ourselves."). During installation, it allowed the distributor to design and configure the system with the customer, while providing performance diagnostics and maintenance insights in the after-sales phase. Another of these service infusion tools was a service portal that the focal firm developed to provide the distributor with detailed schedules, steps, descriptions, and processes by which the system had to be serviced and maintained. With the help of both of these tools, the focal firm codified knowledge and made it available for use by the distributor (externalization); this exemplifies another explicit knowledge exchange mechanism (Focal firm quote: "We have thus developed some tools to build up the competence."). Through training and application, the knowledge captured in those tools was transformed into the tacit knowledge base of the distributor (internalization).

Finally, although marketing activities were the distributors' responsibility, the focal firm also provided marketing support in the form of brochures, animations, trade show displays, demonstration material as well as a demonstration system that could be taken to 
trade shows. Furthermore, the focal firm facilitated access to the system of one of the earlier customers, thereby enabling the distributor to showcase a fully operational system to prospective customers.

On the other hand the distributor took over activities that did not exactly constitute services to the customer, but were done on behalf of the focal firm, such as marketing, sales and customer relationship management (see figure 5: arrow 3). This in turn allowed the focal firm to maintain its slim operation while growing the business through the distributors.

Insert Figure 5 about here

\subsubsection{The reconfigured business model}

In the reconfigured business model of the focal company, the relationship between the focal firm and its now numerous customers became fully defused (Customer firm quote: "[Distributor] is the only partner [customer firm] has the theoretical right to talk to. [Focal firm] is out of our scope. Everything is going though [distributor]"). By reducing the focal firm's involvement (and therefore its relational interactions) with customers, its relationship with the distributors became more important, as it has to provide both the support and knowledge needed in order for these distributors to being able to fully service the customers (including the provision of different product-related and customer-related services). This is critical as the underlying warehouse system is technologically advanced, requiring extensive expert knowledge. As stated by one of the distributors:

"[Focal firm] still have to be a partner. We are selling a complex system. We are not selling mouses or napkins or coffee cups. We are selling a high technological product which is expensive. It is a large investment for our companies. We need to have [focal firm] not just as a producer that delivers components, but to a certain degree we need to have cooperation were we have a dialogue." (Distributor firm) 
In this reconfigured situation, while the achieved business model minimizes the involvement between the focal firm and the customers, the relationship between the focal firm and the distributors became ever more important. To take full advantage of the distributor model and allow scalable growth as well as lean operations, a well-functioning relationship between the focal firm and its distributors, coupled with a well-defined distributor support structure and knowledge exchange mechanisms were key.

Figure 6 depicts the business model after the reconfiguration, in which the distributor is responsible for customer acquisition, as well as planning, integrating, installing, and optimizing the system, providing both product and services to the customer (Distributor firm quote: "We are going to be a system integrator. I think we have achieved this to 95\%."). During the installation, the distributors would often involve external parties who would help with some basic service tasks. To manage the relationships and streamline communication with the customers, the distributors developed dedicated account manager positions. The distributor would also manage all relevant after-sales services on the hard and software elements of the system and independently train the customer on using the system (see figure 6 , arrow $1 \mathrm{~b}$ ). The training for the customer primarily concerns running and maintaining the system and is mainly achieved through tacit as well as explicit knowledge exchange mechanisms between the distributor and the customer (socialization and combining).

The effectiveness of any customer training is to a large extent contingent on the preceding knowledge exchange processes between the focal firm and the distributor. Supported by the training offered, customers continue to build their own expertise in running and maintaining the system, as well as performing repairs. These competencies are essential for customers, as they allow them to decrease their dependence on third parties in terms of operating and maintaining the system, and it allows them to anticipate and react quickly to issues, which is especially important considering that the automated warehouse constitutes a 
key element in their logistics operations, thereby directly affecting their company performance. However, although the customers build up in-depth knowledge about the system, situations occur in which they need support from the distributor. The focal firm, on the other hand, would only get involved directly with the customer in exceptional cases (i.e. where fundamental adaptations to the system need to be made due to special customer requirements; Customer firm quote: "[Distributor] is the gate keeper deciding what to do ... if something is going outside their knowledge area, they are escalating to [focal firm].") and also indirectly by means of the $24 / 7$ 'second line support' (see figure 6: arrow 1a), otherwise the relationship between the focal company and its customers is now service defused (Distributor firm quote: "for second and third level support we need [focal firm]. But all the rest should be done by us.").

The reconfigured business model is characterized by the primary interaction of the focal firm having shifted to the distributor for support and knowledge exchange purposes (see figure 6, arrow 2). This new structure also required adaptations on the governance level of the business model (see figure 6, arrow 4). The focal firm introduced account management teams for each distributor. It holds quarterly business reviews to discuss commercial targets as well as project implementation issues with the distributors. Furthermore, the services that the distributor provides to the customer are specified through service-level agreements between the distributor and the customer. These agreements in turn are enforced through contracts between the distributors and the focal firm. In particular, the training of the customer is crucial, as many errors and system failures occur through improper use and maintenance. However, ensuring proper training (and also monitoring the quality of that training) that the distributor is providing to the customer is a difficult task for the focal firm, as it holds only limited direct control over the relationship between the distributor and the customer. In order to achieve the required standard of knowledge at the customer firm, an accreditation scheme 
has been put in place by the focal firm that codifies the essential knowledge that a user of the system needs to have in order to operate it. For example the focal firm insists on a "superuser" function at the customer (i.e. a dedicated customer employee with technical expertise regarding the system; Focal firm quote: "we tell the distributors many demands that they have to tell their customers. For example, we say that customers need a super-user and what the super-user has to do. We try to tell the distributors, but when they are in a sales position they tend to forget the most obvious things."). The distributor in turn provides training and awards certification according to these standards.

The contract between the focal firm and the distributor serves another important governance purpose, as it defines the performance parameters of the system and provides clear expectations and benchmarks against which the systems can be measured (Distributor firm quote: "the distributor agreement with [focal firm] is a unique contract and not industry standard"). Given that the interactions between the focal firm and the customers have been reduced to a minimum, the former has developed a software tool that allows it to monitor the system at the customer site, thereby ensuring that the system is performing optimally (Focal firm quote: "We really can see it on our system and then we can say: $O K$, this is making too many stops, so this customer may not be so happy and the distributor should really do something."). This tool serves as a relational safeguard by providing a quality control system that essentially monitors the work of the distributors. It also allows the focal firm to perform root-cause analyses of system errors and thereby allows more targeted and timely troubleshooting. Furthermore, it protects the focal firm from claims related to errors that are caused by the distributor or customer. The simulation tool and the service portal constitute mechanisms that indirectly allow the focal firm to bridge the lack of a direct relationship with the customer and ensure that the system is correctly designed, serviced, and maintained (and that the business model is running effectively). Finally, as the markets of the distributors 
overlap to some extent, the focal firm has put a system in place that protects the accounts of distributors from competition by other distributors. To achieve this, the distributor registers and provides details about any new account to the focal firm, which in turn provides discounts off the regular price list. This provides a governance mechanism at the network level to enforce the business model, and disincentivizes distributors from competing with each other for the same customers.

Insert Figure 6 about here

\section{Findings}

Tables 2, 3, and 4 provide summaries of the business model characteristics and the knowledge conversion mechanisms as well as associated capacities involved for each of the three phases underlying the reconfiguration of the focal firm's business model: 1) the business model reconfiguration I, 2) the business model reconfiguration II, and 3) the final business model. According to table 2, the business model reconfiguration I (focal firm service infusion processes) is primarily characterized by developing a service infrastructure for the focal firm's automated warehouse system, and thus primarily affects the content level of the business model (i.e. service infusion processes on the content level). Although both the initial customer and future distributor were involved in this phase, the focal firm took the lead on both service development and service provision. In particular, during this stage the distributor's expertise in planning warehouse solutions and integrating different components into one solution was of value for the focal firm. However, the interactions between the distributor and focal firm were characterized primarily by knowledge creation and exchange. From a structural perspective of the business model, during this stage the focal firm was the central actor in terms of service provision. In terms of the governance level, the business model relied primarily on close and collaborative relationships and not on formal contracts 
among the actors. In addition to having developed a service infrastructure for the focal firm's system (service infusion processes on the content level), a second major goal was to prepare the further reconfiguration of the business model in which the distributor would manage all relevant services associated with the system (service infusion processes on the structural level). To accomplish both goals, tacit knowledge creation (development of novel services for service infusion processes on the content level) and exchange mechanisms and capacities (training of the distributor to facilitate service infusion processes on the structural level) were crucial, given that much of the relevant knowledge had not yet been codified, and was embedded in the focal firm's tacit knowledge base (socialization).

Insert Table 2 about here

As we move into business model reconfiguration II (table 3), the distributors start to take the lead on service provision (service infusion processes on the structural level) with the focal firm withdrawing somewhat (service defusion processes on the structural level). At that stage, the focal firm only gets involved in the service provision to support the distributors in their new role. From a structural perspective, the relationship between the focal firm and its customers is being service defused, and between the distributors and customers is being service infused. To accomplish this change, the relationship between the focal firm and distributor becomes central and new services are developed by the focal firm to facilitate knowledge exchange and support the distributors in their service provision to the customers (service infusion processes on the content level). While the services to the customers essentially remained the same and only the provider of these services changed, novel services have been introduced in the relationship between the focal firm and the distributors on the content level of the focal firm's business model. Tacit knowledge exchange mechanisms and capacities (socialization) still play a crucial role in the business model reconfiguration II; however, the focal firm started to codify knowledge into manuals, trainings and support tools 
(externalization) in order to facilitate explicit knowledge exchange mechanisms (combining and internalization) to reduce some of the transaction costs associated with tacit knowledge exchange mechanisms. On a governance level, the relationship between the focal firm and the customers becomes more discrete (i.e. is being defused) while that between the distributors and the customers becomes more close and cooperative (i.e. is being infused). Although the infused relationships (between distributors and customers; between focal firm and distributors) are close and cooperative, they are increasingly formalized through contractual arrangements (e.g. contracts, service-level agreements).

Insert Table 3 about here

Finally, as the business model reconfigurations are complete (table 4), the relationship between the focal firm and the customers has become defused and that between the distributors and customers has become infused on both a relationship level and in terms of the service provision (service defusion and infusion on the structural level). To maintain this resulting business model, the relationship between the focal firm and the distributors had to be infused with support services (service infusion on the content level). At this final phase, the infused relationships among the actors are primarily governed by contractual arrangements. Further, due to the lack of control of the focal firm over the relationship between the distributors and customers, additional control and governance mechanisms have been put in place to ensure proper service delivery and quality and to safeguard the focal firm from potential opportunistic behaviour of the distributors (these include training control via the accreditation scheme; maintenance control via the service portal; performance and design control via the simulation; and cannibalization control among distributors via the customer registration process). Although tacit knowledge exchange mechanisms and capacities are still important at that stage, a shift to primarily explicit knowledge exchange mechanisms and capacities can be observed. 
Insert Table 4 about here

\section{Conclusions}

We set out to study service infusion and defusion processes as business model reconfigurations. The ability to manage business model reconfiguration constitutes a critical success factor for firms to sustain their competitiveness in fast-paced business environments. The business model concept allowed us to track process developments on three important levels of service infusion and defusion processes: structure, content and governance, as well as highlighting the importance of the underlying knowledge conversion mechanisms and capacities. As illustrated by the case study, service infusion and defusion processes can affect major shifts on all three levels of the business model, and are driven by multiple knowledge creation, transformation, and exchange mechanisms and capacities. Thus, while tacit knowledge creation and exchange mechanisms and capacities are of primary importance for service infusion on a content level, more explicit forms of knowledge exchange mechanisms and capacities support the service infusion on a structural level. From a structural perspective of the business model, service defusion processes play a critical role as the knowledge exchange primarily flows from the defusing to the infusing actor. The defusion process of the relationship between A (defusing actor) and B (recipient of the service) goes hand in hand with the infusion process of the relationship between $\mathrm{C}$ (infusing actor) and $\mathrm{B}$, but also with the infusion process of supporting services in the relationship between the infusing and defusing actors $(\mathrm{C}$ and $\mathrm{A})$. While service infusion processes on a content level require a development towards close, collaborative and less formalized governance mechanisms, service infusion processes on a structural level are primarily governed by the development towards contractual arrangements (e.g. contracts, service-level agreements). Finally, due to a lack of control over defused relationships, the defusing actor may require relationship 
safeguard or control capacities to ensure both the appropriate service delivery and the quality of the service provided by the infused actor.

\subsection{Theoretical and managerial implications}

Our study responds to a recent call for advancing research in service infusion (Ostrom et al., 2010). First, we offer a conceptual understanding of managing service infusion processes as business model reconfigurations (Barquet et al., 2013). This is crucial because of the strategic importance of business model reconfiguration being rooted in firms' need to constantly be able to adapt to forces emanating from their surrounding business environment in an effort to stay competitive (Teece et al., 1997). We contribute to the service infusion literature by further developing a process perspective (in line with Kowalkowski et al., 2012; 2015), which complements the dominant outcome perspective in current research (Baines et al., 2009; Steiner et al., 2014). This perspective allows further insight into how service infusion can be achieved (Neely, 2008; Eggert et al., 2014) by decomposing the complexity around the dynamic and emerging process of service infusion (Biggemann et al., 2013; Ferreira et al., 2012; Kowalkowski et al., 2012; 2013; Matthyssens \& Vandenbempt, 2008). We introduce service infusion processes as business model reconfigurations at three levels: transaction content, transaction structure, and transaction governance, and thereby provide a systematic and granular understanding of the phenomenon (Amit \& Zott, 2001; Zott et al., 2011). For managers this provides guidance regarding the implementation practice of service infusion, for example through the provision of a comprehensive checklist of service infusion process aspects.

Secondly, we contribute by demonstrating the importance of knowledge conversion as underpinning the service infusion processes. Such conversion requires a reconfiguration capacity as part of the dynamic capabilities driving the business model reconfiguration. This is important, as it conceptually outlines the micro foundations of the processes of service 
infusion and thereby links a process view with the crucial underlying mechanisms and capacities driving these processes. We examine the involvement of tacit and explicit knowledge conversion mechanisms (Nonaka, 1994; Polanyi, 1966) to find that tacit knowledge creation and exchange mechanisms as well as capacities are critical for service infusion processes on a content level, while more explicit forms of knowledge exchange become increasingly relevant with respect to the structural level of service infusion processes. We thus complement and build on specific considerations by Kindström and colleagues (2013) on the micro foundations of service infusion. This provides important managerial implications as it highlights knowledge conversion capacities as being central to implementation practices of service infusion. Thus, a knowledge-based reconfiguration capacity needs to be built, for example by including different knowledge conversion mechanisms as part of monitoring key success factors of the service infusion implementation. This would require ambidextrous knowledge management capacities (Kang \& Snell, 2009), such as building communities of practice or distributed knowledge databases, which allow managers to utilize knowledge conversion for tacit as well as explicit knowledge types (see tables $2-4$ for examples).

Thirdly, we introduce the crucial concept of service defusion as an essential counterpart of the service infusion phenomenon. The concepts of service defusion and infusion are often argued to be linked in practice, and together enable researchers to fully capture firms' movements on the transaction content continuum, as well as their engagement and disengagement of important business partners, i.e. the transaction structure. Service infusion and defusion therefore capture important processes for services-related business model reconfiguration. As suggested by the service infusion literature, staying competitive in a changing business environment requires firms to move up the product-service continuum as well as to engage additional business partners, but it also means being flexible in the opposite 
direction (i.e. move down the product-service continuum and disengaging business partners) or to restructure the service provision among actors (Kowalkowski et al., 2012, 2013), as illustrated in the case. Certain solutions may need to be disintegrated, scaled down, or discontinued while others my need to be provided by a different actor in the network. By enriching service infusion research through the concept of service defusion, our study demonstrates the bi-directionality of the service-related processes of the business model reconfiguration. From a managerial perspective, this encourages managers to assess a wider option space in their strategic decision making, which may include increasing, but also decreasing the service offering component for business model reconfiguration. This allows managers to reframe and thereby enrich their understanding of service infusion as a strategic option and therefore optimizes their theories-in-use about the importance of services as part of their companies' business models.

Fourthly, by employing the business model framework, our study shows that service infusion processes may require an antagonistic service defusion process and vice versa in order to achieve an equilibrium across all business model reconfiguration levels. This is important as it demonstrates the systemic complexity of adding or subtracting service elements in an industrial context, and thus complements research on business network dynamics (Halinen et al., 1999). Furthermore, in this context our study complements the emerging literature on service infusion in business networks (Kowalkowski et al., 2013; Ostrom et al., 2010). We illustrate how service infusion as a business model reconfiguration may depend not only on the relationship between the infusing actor and the recipient of the service, but also on the relationship between the defusing and infusing actors. As a consequence, further support through knowledge exchange mechanisms, and governance through control mechanisms are required to ensure service delivery performance and safeguard against potential opportunism by business partners. Implications for managers 
relate to the fact that as part of managing a business model reconfiguration, firms may not only need to focus on the processes and mechanisms under their direct control, but also need to mobilize and assist other involved actors in their complementary infusion and defusion processes through knowledge conversion mechanisms, e.g. training, provision of service manuals, or joint problem-solving, and through governance mechanisms, e.g. monitoring systems, accreditation schemes, or detailed contractual arrangements.

Overall, by understanding service infusion processes through the business model concept and its reconfiguration, we offer a conceptual grounding for further theory and concept development. We thereby provide a conceptual integration of the business model concept, in particular with regard to reconfiguration processes, and the specific knowledge conversion mechanisms involved, and link them with reconfiguration capacities from a dynamic capabilities perspective.

\subsection{Limitations and future research}

As with any research, this study is not without limitations. We employ an instrumental multi-actor longitudinal illustrative case study (Flyvbjerg, 2006; Stake, 2000). The methodology and research design was deemed appropriate for the objectives set: to exemplify and further explore both the business model reconfiguration processes, and the knowledge conversion mechanisms associated with service infusion and service defusion processes. The adoption of a typical case sampling allowed thickening and solidifying of the developed conceptual framework via a 'normal' case. Our case considered all relevant network actors involved in a focal company's business model reconfiguration, thereby taking multiple perspectives into account. However, future research could include a multiple case study design across different network settings, which would facilitate an investigation into the replicability of the findings in other contexts, as well as the generalizability of the conceptual framework (Kaplan \& Goldsen, 1965; Yin, 1994). This ought to include an understanding of 
performance issues of service infusion and defusion processes (including strategic limitations of service infusion and defusion business models), as well as a contingency perspective about contextual elements, which affect such business model reconfigurations (Kowalkowski et al., 2012).

Additionally, while the case allowed for the illustration of service infusion processes on both the content and structural levels, service defusion could only be shown on the structural level. Future research should investigate more in-depth issues around service defusion on a content level. Furthermore, the literature on governance around service infusion has not developed to a similar level of detail to that of the content and structural elements. We integrate relationship governance into our discussion and link service infusion and defusion at content and structural level to specific governance types, however, we do not derive propositions as to governance implications for each infusion/defusion process. Therefore, while our research makes an initial step towards understanding the governance implications of service infusion, future research needs to explicitly focus on the role of governance.

While we contribute through a conceptualization of service infusion (and defusion) processes as business model reconfigurations, based on knowledge conversion mechanisms, further theory development is necessary in this area. In particular, we put emphasis on the knowledge conversion mechanisms involved, while future research needs to systematically explore the associated reconfiguration capacities and their development, as well as study reconfiguration capacities other than those related to knowledge conversion. Furthermore, service infusion necessitates a certain ambidexterity, i.e. juggling service-related as well as product-related capabilities and orientations. Further research could look at how this organizational ambidexterity changes as a consequence (or even as an antecedent) of service 
infusion business model reconfigurations, and in what ways this affect the competitive situation of the firm, e.g. vis-à-vis potentially disruptive innovations. 


\section{References}

Amit, R. \& Zott, C. (2001). Value Creation in E-business. Strategic Management Journal, 22 (6/7), 493-520.

Anderson, J. C. \& Narus, J. A. (1995). Capturing the Value of Supplementary Services. Harvard Business Review, 73 (1), 75-83.

Arzaghi, M, Berndt, E. R., Davis, J. C., \& Silk, A. J. (2012). The Unbundling of Advertising Agency Services: An Economic Analysis. Review of Marketing Science, 10 (4), 1-53.

Baines, T. S., Lightfoot, H. W., Benedettini, O., \& Kay, J. M. (2009). The Servitization of Manufacturing: A Review of Literature and Reflection on Future Challenges. Journal of Manufacturing Technology Management, 20 (5), 547-567.

Barquet, A. P. B., de Oliveira, M. G., Amigo, C. R., Cunha, V. P., \& Rozenfeld, H. (2013). Employing the Business Model Concept to Support the Adoption of Product-Service Systems (PSS). Industrial Marketing Management, 42 (5), 693-704.

Biggemann, S., Kowalkowski, C., Maley, J., \& Brege, S. (2013). Development and Implementation of Customer Solutions: A Study of Process Dynamics and Market Shaping. Industrial Marketing Management, 42 (7), 1083-1092.

Bjurklo, M., Edvardsson, B., \& Gebauer, H. (2009). The Role of Competence in Initiating the Transition from Product to Services. Managing Service Quality, 19 (5), 493-510.

Blumenberg, S., Wagner, H.-T., \& Beimborn, D. (2009). Knowledge Transfer Processes in IT Outsourcing Relationships and their Impact on Shared Knowledge and Outsourcing Performance. International Journal of Information Management, 29 (5), 342-352.

Brax, S. (2005). A Manufacturer Becoming Service Provider - Challenges and a Paradox. Managing Service Quality, 15 (2), 142-155.

Brax, S. \& Jonsson, K. (2009). Developing Integrated Solution Offerings for Remote Diagnostics: A Comparative Case Study of two Manufacturers. International Journal of Operations \& Production Management, 29 (5), 539-560.

Brito, C. M. (1999). Issue-based Nets: A Methodological Approach to the Sampling Issue in Industrial Networks Research. Qualitative Marketing Research: An International Journal, 2 (2): 92-102.

Brown, J. S. and Duguid, P. (1991). Organizational Learning and Communities-of-Practice: Toward a Unified View of Working, Learning, and Innovation. Organization Science, 2 (1), 40-57.

Buchanan, D., Boddy, D., \& McCalman, J. (1988). Getting in, Getting on, Getting out and Getting back. In Bryman, A., (Ed.), Doing Research in Organizations (pp. 53-67). London: Routledge.

Calia, R. C., Guerrini, F. M., \& Moura, G. L. (2007). Innovation Networks: From Technological Development to Business Model Reconfiguration. Technovation, 27(8), 426-432.

Cantú, C., Corsaro, D., \& Snehota, I. (2012). Roles of Actors in Combining Resources into Complex Solutions. Journal of Business Research, 65 (2), 139-150.

Chesbrough, H. (2010). Business Model Innovation: Opportunities and Barriers. Long Range Planning, 43(2), 354-363. 
Cova, B. \& Salle, R. (2008). Marketing Solutions in Accordance with S-D Logic: Co-creating Value with Customer Network Actors. Industrial Marketing Management, 37 (3), 270277.

Davies, A. (2004). Moving Base into High-value Integrated Solutions: A Value Stream Approach. Industrial and Corporate Change, 13 (5), 727-756.

Denzin, N. K. \& Lincoln, Y. S. (2000). Handbook of Qualitative Research. (2nd ed). Thousand Oaks, CA: Sage Publications.

Dubois, A. \& Gadde, L.-E. (2002). Systematic Combining: An Abductive Approach to Case Research. Journal of Business Research, 55 (7), 553-560.

Dubois, A. \& Araújo, L. (2007). Case Research in Purchasing and Supply Management: Opportunities and Challenges. Journal of Purchasing and Supply Management, 13 (3), $170-81$.

Dubois, A. \& Gibbert, M. (2010). From Complexity to Transparency: Managing the Interplay between Theory, Method and Empirical Phenomena in IMM Case Studies. Industrial Marketing Management, 39 (1), 129-136.

Easterby-Smith, M., Lyles, M. A., \& Tsang, E. W. K. (2008). Inter-organizational Knowledge Transfer: Current Themes and Future Prospects. Journal of Management Studies, 45 (4), 677-690.

Easterby-Smith, M. \& Prieto, I. M. (2007). Dynamic Capabilities and Knowledge Management: an Integrative Role for Learning? British Journal of Management, 19 (3), 235-249.

Eisenhardt, K. M. (1989). Building Theories from Case Study Research. Academy of Management Review, 14 (4), 532-550.

Eisenhardt, K. M. \& Bourgeois III, L. J. (1988). Politics of Strategic Decision Making in High-velocity Environments: Toward a Midrange Theory. Academy of Management Journal, 31 (4), 737-770.

Eggert, A., Hogreve, J., Ulaga, W., \& Muenkhoff, E. (2011). Industrial Services, Product innovations and Firm profitability: A Multi-group Latent Growth Curve Analysis. Industrial Marketing Management, 40 (5), 661-670.

Eggert, A., Hogreve, J., Ulaga, W., \& Muenkhoff, E. (2014). Revenue and Profit Implications of Industrial Service Strategies. Journal of Service Research, 17 (1), 23-39.

Ernst, D. \& Kim, L. (2002). Global Production Networks, Knowledge Diffusion, and Local Capability Formation. Research Policy, 31 (8-9), 1417-1429.

Fang, E., Palmatier, R. W., \& Steenkamp, J.-B. E. M. (2008). Effect of Service Transition Strategies on Firm Value. Journal of Marketing, 72 (5), 1-14.

Ferreira, F. N. H., Proença, J., Spencer, R., \& Cova, B. (2013). The Transition from Products to Solutions: External Business Model Fit and Dynamics. Industrial Marketing Management, 42 (7), 1093-1101.

Flyvbjerg, B. (2006). Five Misunderstandings about Case Study Research. Qualitative Enquiry. 12 (2), 219-245.

Frambach, R. T., Wels-Lips, I., \& Gündlach, A. (1997). Proactive Product Service Strategies: An Application in the European Health Market. Industrial Marketing Management, 26 (4), 341-352. 
Gambardella, A., \& McGahan, A. M. (2010). Business-model innovation: General Purpose Technologies and their Implications for Industry Structure. Long Range Planning, 43(2), 262-271.

Gebauer, H. \& Friedli, T. (2005). Behavioral Implications of the Transition Process from Products to Services. Journal of Business and Industrial Marketing, 20 (2), 70-78.

Gebauer, H. (2008). Identifying Service Strategies in Product Manufacturing Companies by Exploring Environment-Strategy Configurations. Industrial Marketing Management, 37 (3), 278-291.

Gebauer, H., Edvardsson, B., Gustafsson, A., \& Witell, L. (2010). Match or Mismatch: Strategy-Structure Configurations in the Service Business of Manufacturing Companies. Journal of Service Research, 13 (2), 198-215.

Gebauer, H., Paiola, M., \& Saccani, N. (2013). Characterizing Service Networks for Moving from Products to Solutions. Industrial Marketing Management, 42 (1), 31-46.

Gibbert, M., Ruigrok, W., \& Wicki, B. (2008). What Passes as a Rigorous Case Study? Strategic Management Journal, 29 (13), 1465-1474.

Glaser, B. G. \& Strauss, A. L. (1967). The Discovery of Grounded Theory. Chicago: Aldine.

Glick, W. H., Huber, G. P., Miller, C. C., Doty, D. H., \& Sutcliffe, K. M. (1990). Studying changes in organizational design and effectiveness: Retrospective event histories and periodic assessments. Organization Science, 1 (3), 293-312.

Grant, R. M. (1996). Toward a Knowledge-based Theory of the Firm. Strategic Management Journal, 17 (S2), 109-122.

Gray, D. E. (2004). Doing Research in the Real World. London: Sage Publications.

Halinen, A., Salmi, A., \& Havila, V. (1999). From Dyadic Change to Changing Business Networks: An Analytical Framework. Journal of Management Studies, 36 (6), 779-794.

Hartley, J. (2004). Case Study Research. In Cassell, C. \& G. Symon (Eds.), Essential Guide to Qualitative Methods in Organizational Research (pp. 324-333). London: Sage.

Homburg, C., Fassnacht, M., \& Guenther, C. (2003). The Role of Soft Factors in Implementing a Service-oriented Strategy in Industrial Marketing Companies. Journal of Business-to-Business Marketing, 10 (2), 23-51.

Huber, G. P. \& Power, D. J. (1985). Retrospective Reports of Strategic-level Managers: Guidelines for Increasing their Accuracy. Strategic Management Journal, 6 (2), 171-180.

Inkpen, A. C. (2008). Knowledge transfer and international joint ventures: the case of NUMMI and General Motors. Strategic Management Journal, 29 (4), 447-453.

Jaakkola, E. \& Hakanen, T. (2013). Value Co-creation in Solution Networks. Industrial Marketing Management, 42 (1), 47-58.

Jick, T. D. (1979). Mixing Qualitative and Quantitative Methods: Triangulation in Action. Administrative Science Quarterly, 24 (4), 602-611.

Johnson, M. W., Christensen, C., \& Kagermann, H. (2008). Reinventing your Business Model. Harvard Business Review, 86 (12), 57-68.

Kang, S.-C. \& Snell, S. A. (2009). Intellectual Knowledge Architectures and Ambidextrous Learning: A Framework for Human Resource Management. Journal of Management Studies, 46 (1), 67-90. 
Kaplan, A. \& Goldsen, J. M. (1965). The Reliability of Content Analysis Categories. In Lasswell, H. \& N. Leites (Eds.). Language of Politics: Studies in Quantitative Semantics (pp. 83-112). Cambridge: MIT Press.

Kindström, D. (2010). Towards a Service-based Business Model - Key Aspects for Future Competitive Advantage. European Management Journal, 28 (6), 479-490.

Kindström, D. \& Kowalkowski, C. (2009). Development of Industrial Service Offerings: A Process Framework. Journal of Service Management, 20 (2), 156-172.

Kindström, D., Kowalkowski, C., \& Sandberg, E. (2013). Enabling Service Innovation: A Dynamic Capability Approach. Journal of Business Research, 66 (8), 1063-1073.

Koza, M. P. \& Lewin, A. Y. (1999). The coevolution of network alliances: A longitudinal analysis of an international professional service network. Organization Science, 10 (5), 638-653.

Kowalkowski, C., Kindström, D., Alejandro, T. B., Brege, S., \& Biggemann, S. (2012). Service Infusion as Agile Incrementalism in Action. Journal of Business Research, 65 (6), $765-772$.

Kowalkowski, C., Windahl, C., Kindström, D., \& Gebauer, H. (2015). What Service Transition? Rethinking Established Assumptions about Manufacturers' Service-led Growth Strategies," Industrial Marketing Management, 45, 59-69.

Kowalkowski, C., Witell, L., \& Gustafsson, A. (2013). Any Way Goes: Identifying Value Constellations for Service Infusion in SMEs. Industrial Marketing Management, 42 (1), 18-30.

Krippendorff, K. (2004). Content Analysis. Thousand Oaks: Sage.

Langley, A. (1999). Strategies for Theorizing from Process Data. Academy of Management Review, 24 (4), 691-710.

Löfberg, N., Witell, L., \& Gustafsson, A. (2010). Service Strategies in a Supply Chain. Journal of Service Management, 21 (4), 427-440.

Mason, J. (1996). Qualitative Researching. London: Sage.

Mason, K. J. \& Leek, S. (2008). Learning to Build a Supply Network: An Exploration of Dynamic Business Models. Journal of Management Studies, 45 (4), 774-799.

Mathieu, V. (2001a). Service Strategies within the Manufacturing Sector: Benefits, Costs and Partnership. International Journal of Service Industry Management, 12 (5), 451-475.

Mathieu, V. (2001b). Product Services: From a Service Supporting the Product to a Service Supporting the Client. Journal of Business and Industrial Management, 16 (1), 39-58.

Matthyssens, P. \& Vandenbempt, K. (1998). Creating Competitive Advantage in Industrial Services. Journal of Business \& Industrial Marketing, 13 (4/5), 339-355.

Matthyssens, P. \& Vandenbempt, K. (2008). Moving from Basic Offerings to Value-added Solutions: Strategies, Barriers and Alignment. Industrial Marketing Management, 37 (3), 316-328.

Mattsson, L.-G. (1973). System Selling as a Strategy on Industrial Markets. Industrial Marketing Management, 3 (2), 107-120.

Morris, M., Schindehutte, M., \& Allen, J. (2005). The Entrepreneur's Business Model: Toward a Unified Perspective. Journal of Business Research, 58(6), 726-735. 
Mason, K. J., \& Leek, S. (2008). Learning to Build a Supply Network: An Exploration of Dynamic Business mModels. Journal of Management Studies, 45(4), 774-799.

Neely, A. (2008). Exploring the Financial Consequences of the Servitization of Manufacturing. Operations Management Research, 1 (2), 103-118.

Nenonen, S. \& Storbacka, K. (2010). Business Model Design: Conceptualizing Networked Value Co-creation. Journal of Quality and Services Science, 2 (1), 43-59.

Neu, W. A. \& Brown, S. W. (2005). Forming Successful Business-to-Business Services in Goods-Dominant Firms. Journal of Service Research, 8 (1), 3-17.

Nonaka, I. (1994). A Dynamic Theory of Organizational Knowledge Creation. Organization Science, 5 (1), 14-37.

Nonaka, I. \& Takeuchi, H. (1995). The Knowledge-Creating Company: How Japanese Companies Create the Dynamics of Innovation. New York: Oxford University Press.

Nordin, F. \& Kowalkowski, C. (2010). Solution Offerings: A Critical Review and Reconceptualization. Journal of Service Management, 21 (4), 441-459.

Oliva, R. \& Kallenberg, R. (2003). Managing the Transition from Products to Services. International Journal of Service Industry Management, 14 (2), 160-172.

Osterwalder, A. (2004). The Business Model Ontology: A Proposition in a Design Science Approach. These Présentée à l'Ecole des Hautes Etudes Commerciales de l'Université de Lausanne.

Ostrom, A. L., Bitner, M. J., Brown, S. W., Burkhard, K. A., Goul, M., Smith-Daniels, V., Demirkan, H., \& Rabinovich, E. (2010). Moving Forward and Making a Difference: Research Priorities for the Science of Service. Journal of Service Research, 13 (1), 4-36.

Penttinen, E. \& Palmer, J. (2007). Improving Firm Positioning through Enhanced Offerings and Buyer-Seller Relationships. Industrial Marketing Management, 36 (5), 552-564.

Polanyi, M. (1966). The Tacit Dimension, New York: Anchor Day Books.

Punch, K. F. (1998). Introduction to Social Research: Quantitative and Qualitative Approaches, London: Sage Publications.

Raddats, C. \& Easingwood, C. (2010). Service Growth Options for B2B Product-centric Businesses. Industrial Marketing Management, 39 (8), 1334-1345.

Ritchie, J. \& Lewis, J. (2003). Qualitative Research Practice: A Guide for Social Sciences Students and Researchers. London: Sage Publications.

Robson, C. (2002). Real World Research. (2nd ed.). Oxford: Basil Blackwell.

Ryals, L. J. \& Humphries, A. S. (2007). Managing Key Business-to-Business Relationships: What Marketing can learn from Supply Chain Management. Journal of Service Research, $9(4), 312-326$.

Sandstrom, C., \& Osborne, R. G. (2011). Managing Business Model Renewal. International Journal of Business and Systems Research, 5(5), 461-474.

Shankar, V., Berry, L. L., \& Dotzel, T. (2009). A Practical Guide to Combining Products and Services. Harvard Business Review, 87 (11), 94- 99.

Silverman, D. (2000). Doing Qualitative Research: a Practical Handbook. London: Sage Publications. 
Simonin, B. L. (1999). Ambiguity and the Process of Knowledge Transfer in Strategic Alliances. Strategic Management Journal, 20 (7), 595-623.

Smangs, M. (2006). The Nature of the Business Group: A Social Network Perspective. Organization, 13 (6), 889-909.

Spring, M. \& Araújo, L. (2013). Beyond the Service Factory: Service Innovation in Manufacturing Supply Networks. Industrial Marketing Management, 42 (1), 59-70.

Stake, R. E. (2000). Case Studies. In Denzin, N. \& Y. Lincoln (Eds.). Handbook of Qualitative Research (pp. 435-454). (2nd ed.). Thousand Oaks, CA: Sage Publications.

Steiner, M., Eggert, A., Ulaga, W. \& Backhaus, K. (2014). Do Customized Service Packages Impede Value Capture in Industrial Markets? Journal of the Academy of Marketing Science, p. 1-15.

Storbacka, K. (2011). A Solution Business Model: Capabilities and Management Practices for Integrated Solutions. Industrial Marketing Management, 40 (5), 699-711.

Strauss, A. \& Corbin, J. (1990). Basics of Qualitative Research: Grounded Theory Procedures and Techniques. London: Sage Publications.

Stremersch, S. \& Tellis, G. J. (2002). Strategic Bundling of Products and Prices: A New Synthesis for Marketing. Journal of Marketing, 66 (1), 55-72.

Stremersch, S., Wuyts, S., \& Frambach, R. T. (2001). The Purchasing of Full-service Contracts: An Exploratory Study within the Industrial Maintenance Market. Industrial Marketing Management, 30 (1), 1-12.

Szulanski, G. (1996). Exploring Internal Stickiness: Impediments to the Transfer of Best Practice within the Firm. Strategic Management Journal, 17 (S2), 27-43.

Teece, D. J. (2007). Explicating Dynamic Capabilities: The Nature and Microfoundations of (Sustainable) Enterprise Performance. Strategic Management Journal, 28 (13), 13191350 .

Teece, D. J. (2010). Business Models, Business Strategy and Innovation. Long Range Planning, 43 (2-3), 172-194.

Teece, D. J., Pisano, G., \& Shuen, A. (1997). Dynamic Capabilities and Strategic Management. Strategic Management Journal, 18 (7), 509-533.

Tuli, K. R., Kohli, A. K., \& Bharadwaj, S. G. (2007). Rethinking Customer Solutions: From Product Bundels to Relational Processes. Journal of Marketing, 71 (3), 1-17.

Ulaga, W. \& Reinartz, W. J. (2011). Hybrid Offerings: How Manufacturing Firms Combine Goods and Services Successfully. Journal of Marketing, 75 (6), 5-23.

Vandermerwe, S. \& Rada, J. (1988). Servitization of Business: Adding Value by Adding Services. European Management Journal, 6 (4), 314-324.

Windahl, C. \& Lakemond, N. (2006). Developing Integrated Solutions: The Importance of Relationships within the Network. Industrial Marketing Management, 35 (7), 806-818.

Wise, R. \& Baumgartner, P. (1999). Go Downstream: The New Profit Imperative in Manufacturing. Harvard Business Review, 77 (5), 133-141.

Wirtz, B. W., Pistoia, A., Ullrich, S., \& Göttel, V. (2016). Business Models: Origin, Development and Future Research Perspectives. Long Range Planning, 49 (1), 36-54.

Yin, R. K. (1993). Applications of Case Study Research. Sage Publications. 
Yin, R. K. (1994). Case Study Research: Design and Methods. (2nd ed.). London: Sage Publications.

Zander, U. \& Kogut, B. (1995). Knowledge and the Speed of the Transfer and Imitation of Organizational Capabilities: An Empirical Test. Organization Science, 6 (1), 76-92.

Zeithaml, V.A., Brown, S. W., Bitner M. J., \& Salas, J. (2014) Profiting from Services and Solutions. New York: Business Expert Press.

Zollo, M. \& Winter, S. G. (2002). Deliberate Learning and the Evolution of Dynamic Capabilities. Organization Science, 13 (3), 339-351.

Zott, C., Amit, R., \& Massa, L. (2011). The Business Model: Recent Developments and Future Research. Journal of Management, 37 (4), 1019-1042. 
FIGURE 1

Business Model Reconfiguration: Service Infusion Processes

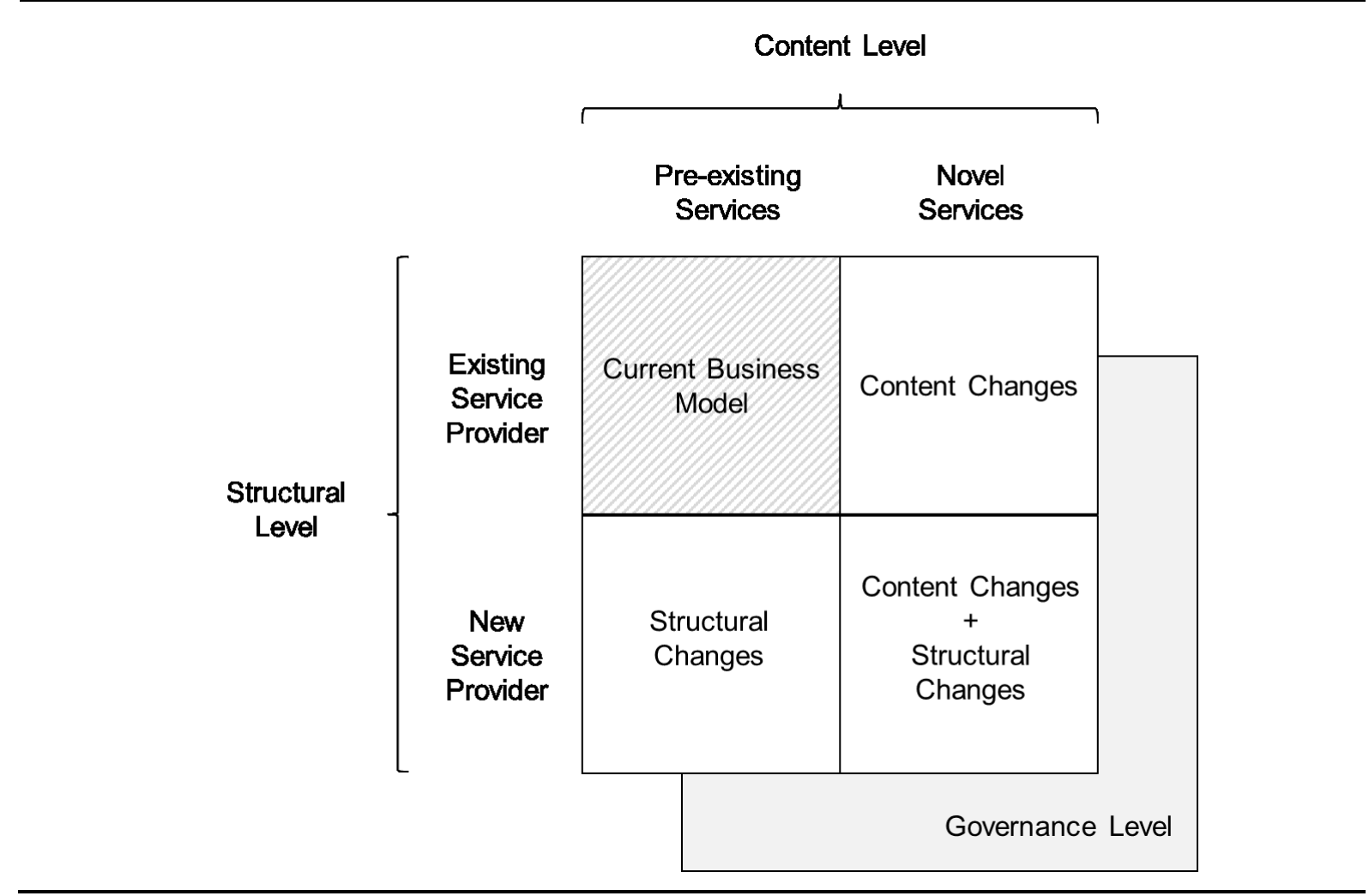

Note: Patterned quadrant indicates static situation 
FIGURE 2

Business Model Reconfiguration Framework: Service Infusion and Service Defusion Processes

Content Level Structural Level

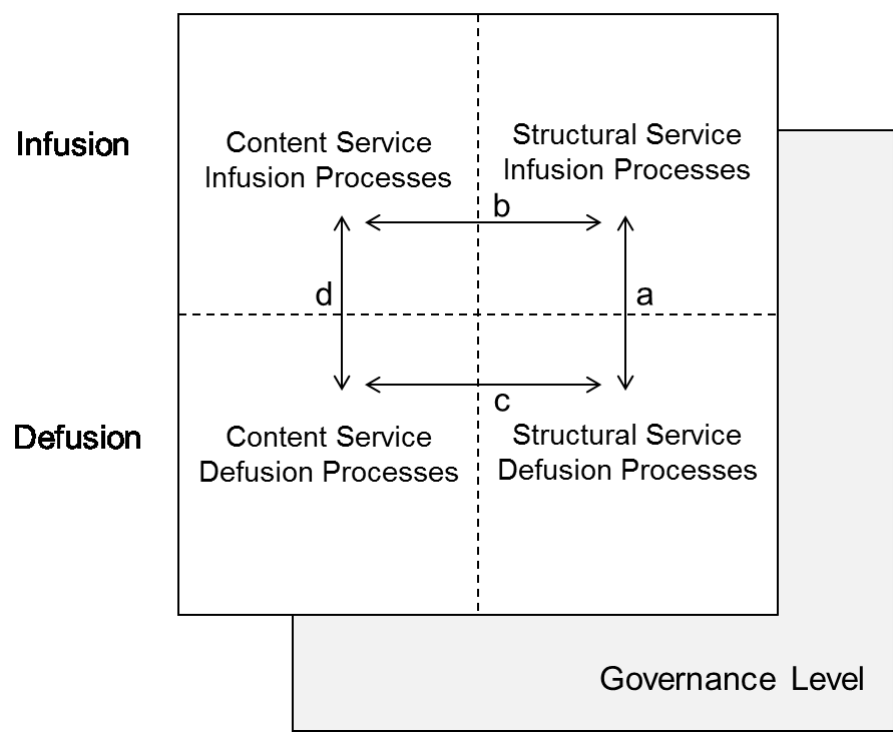

Note: a - d explained in text 
FIGURE 3

Knowledge Exchange and Creation in Business Model Reconfiguration

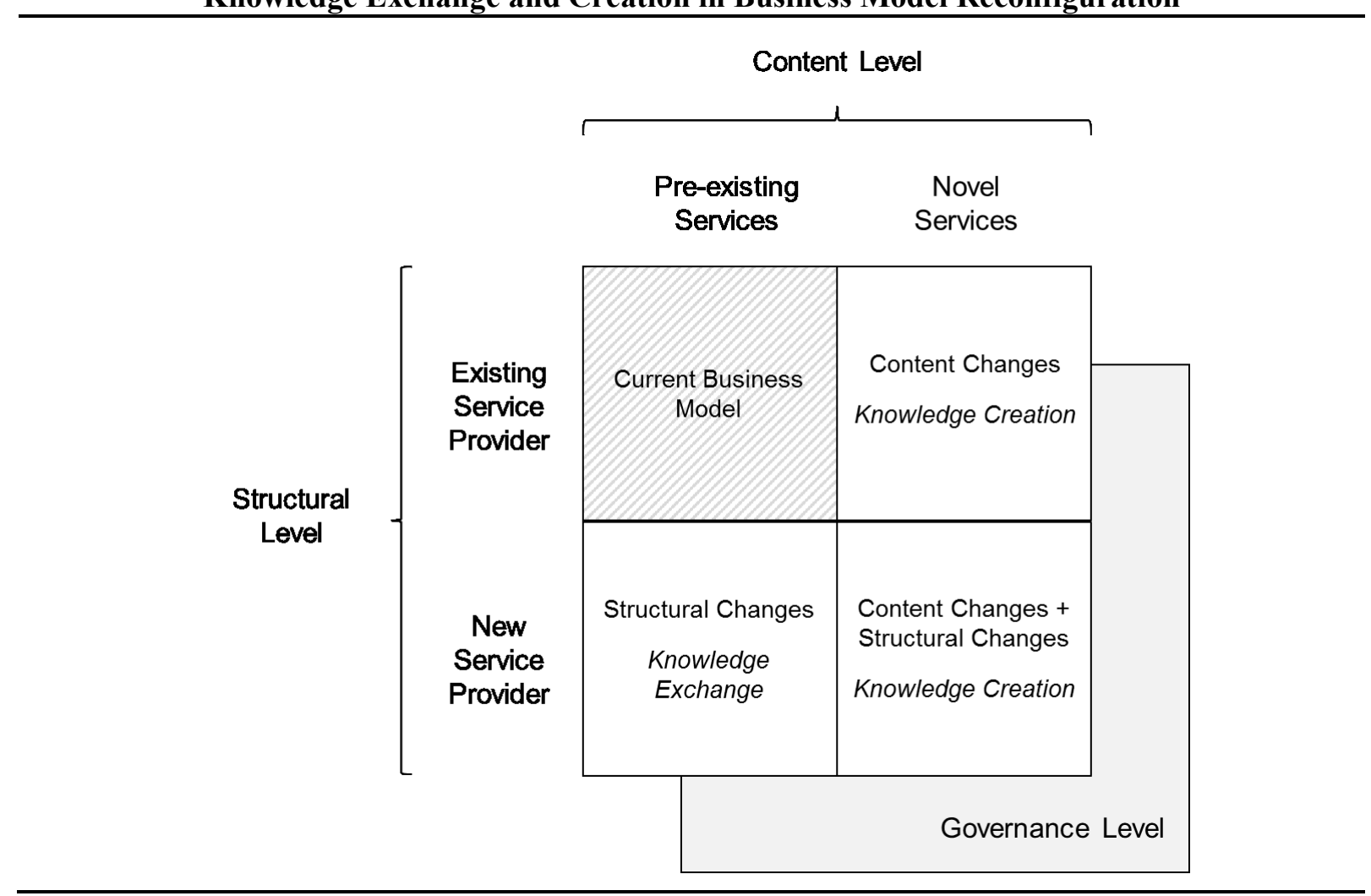

Note: Patterned quadrant indicates static situation 
FIGURE 4

The Beacon Customer Phase: Business Model Re-configuration I through Focal Firm Service Infusion Processes

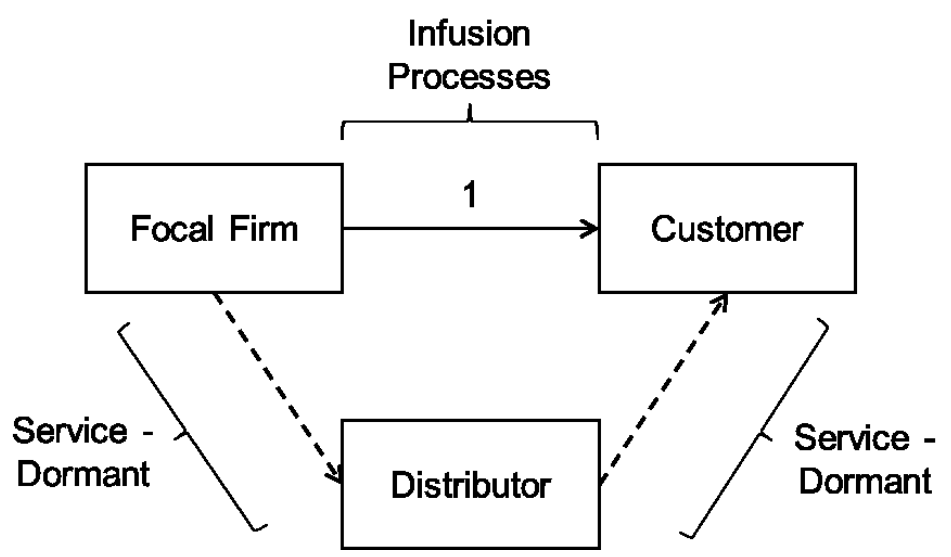

Note: 1 explained in text 
FIGURE 5

The Distributor Development Phase: Business Model Re-configuration II through Focal Firm Service Defusion Processes

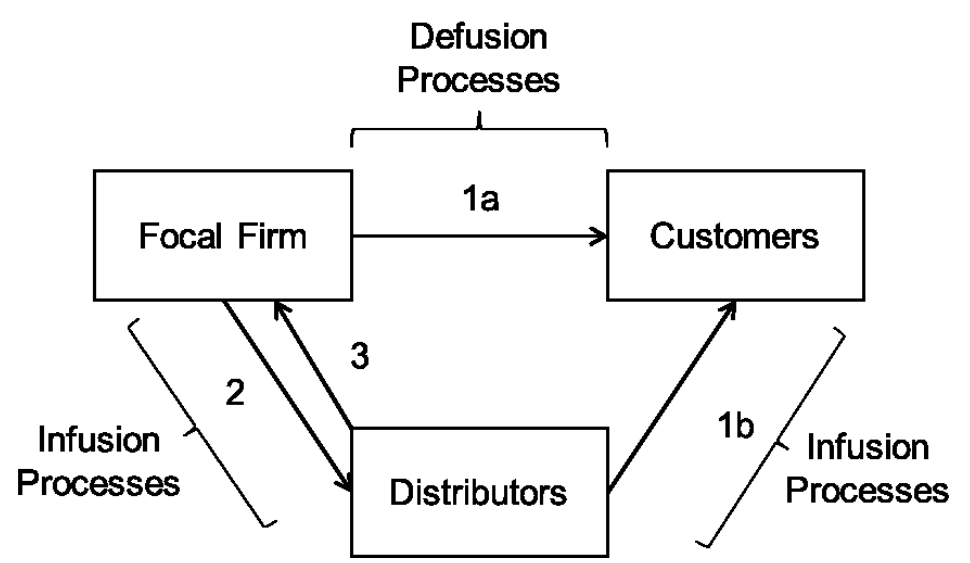

Note: 1 - 3 explained in text 
FIGURE 6

Reconfigured Business Model

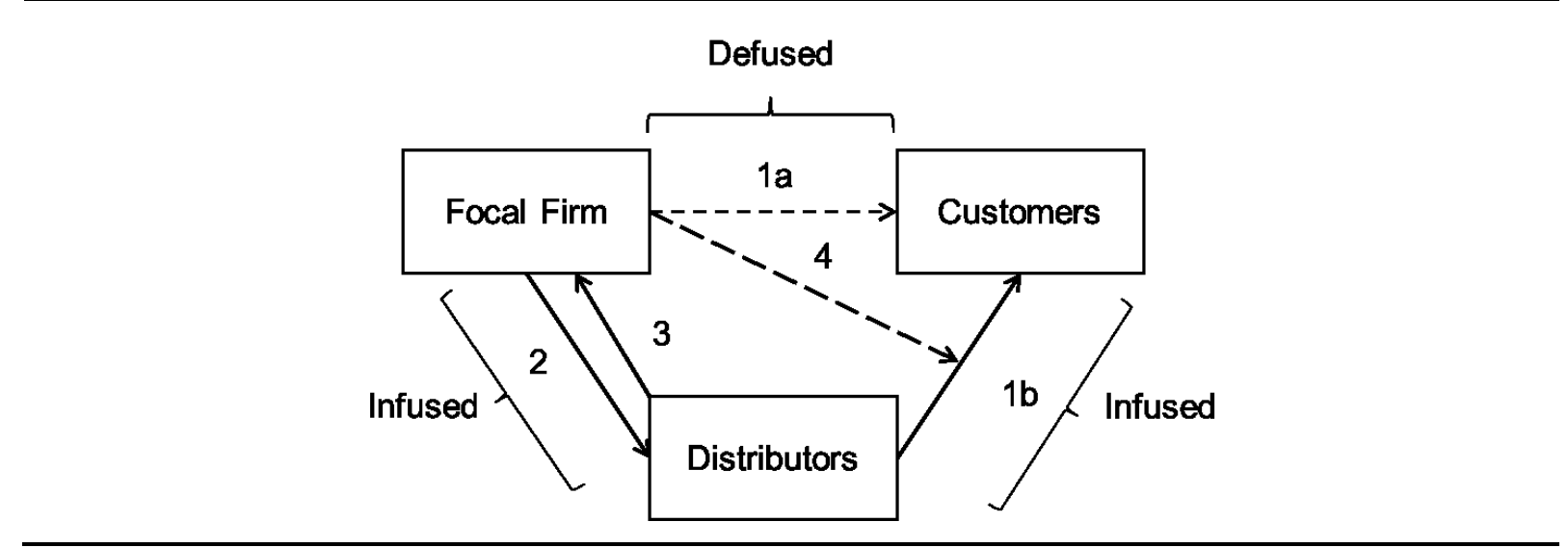

Note: 1 - 4 explained in text 
TABLE 1

Overview of Interviewees

\begin{tabular}{ll}
\hline Firm & Interviewee \\
\hline Focal Firm & $\begin{array}{l}\text { Founder (3 interviews) } \\
\text { Marketing Manager (2 interview) } \\
\text { Sales Manager (1 interview) } \\
\text { Software Engineer (4 interviews) }\end{array}$ \\
& \\
Distributor Firms & \\
$\quad \begin{array}{l}\text { Distributor 1 } \\
\text { Distributor 2 }\end{array}$ & $\begin{array}{l}\text { Sales/Product Manager (2 interviews) } \\
\text { Sales/Product Manager (2 interviews) }\end{array}$ \\
Customer Firms & \\
$\begin{array}{l}\text { Customer 1 } \\
\text { (Wholesaler, Electrical supplies) }\end{array}$ & Warehouse Manager (1 interview) \\
$\begin{array}{l}\text { Customer 2 } \\
\text { (Wholesaler, Electrical products) }\end{array}$ & Logistics IT Manager (1 interview) \\
$\begin{array}{l}\text { Customer 3 } \\
\text { (E-tailer, Home electronics) }\end{array}$ & Chief Operating Officer (1 interview) \\
$\begin{array}{l}\text { Customer 4 } \\
\text { (Distributor, IT products) }\end{array}$ & Warehouse Manager (1 interview) \\
\hline
\end{tabular}


TABLE 2

Business Model Characteristics and Knowledge Conversion Mechanisms: Business Model Reconfiguration I

\begin{tabular}{|c|c|c|c|}
\hline Structural Level & Content Level & Governance Level & $\begin{array}{c}\text { Knowledge Conversion Mechanisms and } \\
\text { Capacities }\end{array}$ \\
\hline $\begin{array}{l}\text { Focal Firm } \rightarrow \\
\text { Customer }\end{array}$ & $\begin{array}{l}\text { - Installation } \\
\text { - Planning and integration } \\
\text { - Spare part delivery } \\
\text { - Maintenance and repair services } \\
\text { - Upgrades } \\
\text { - Optimization } \\
\text { - Trouble shooting } \\
\text { - Training }\end{array}$ & $\begin{array}{l}\text { - Very close and cooperative relationship } \\
\text { - High levels of commitment and } \\
\text { communication across all hierarchical levels } \\
\text { between the focal firm and initial customer } \\
\text { - Not formalized }\end{array}$ & $\begin{array}{l}\text { - Knowledge exchange \& creation through } \\
\text { primarily tacit-to-tacit mechanisms } \\
\text { (socialization): practically involving } \\
\text { customer in servicing and operating the } \\
\text { system } \\
\text { - Customer feedback to focal firm on how to } \\
\text { improve the system }\end{array}$ \\
\hline $\begin{array}{l}\text { Focal Firm } \rightarrow \\
\text { Distributor }\end{array}$ & $\begin{array}{l}\text { - No explicit service transactions. Relationship } \\
\text { primarily characterized by knowledge } \\
\text { exchange and creation }\end{array}$ & $\begin{array}{l}\text { - Very close and cooperative relationship } \\
\text { - High levels of commitment and } \\
\text { communication across all hierarchical levels } \\
\text { between the focal firm and initial customer } \\
\text { - Not formalized }\end{array}$ & $\begin{array}{l}\text { - Knowledge exchange \& creation through } \\
\text { primarily tacit-to-tacit mechanisms } \\
\text { (socialization): practically involving } \\
\text { distributor in all relevant stages (planning, } \\
\text { installing, integrating, optimizing, servicing } \\
\text { the system) }\end{array}$ \\
\hline $\begin{array}{l}\text { Distributor } \rightarrow \\
\text { Customer }\end{array}$ & $\begin{array}{l}\text { Planning and integrating the automated } \\
\text { warehouse in the existing warehouse of the } \\
\text { customer, which was, however, primarily } \\
\text { mediated through the focal firm }\end{array}$ & $\begin{array}{l}\text { Discrete and limited relationship confined to } \\
\text { warehouse planning and integration } \\
\text { mediated by the focal firm }\end{array}$ & $\begin{array}{l}\text { - No particular knowledge exchange or } \\
\text { creation }\end{array}$ \\
\hline $\begin{array}{l}\text { Distributor } \rightarrow \text { Focal } \\
\text { Firm }\end{array}$ & $\begin{array}{l}\text { - No explicit service transactions. Relationship } \\
\text { primarily characterized by knowledge } \\
\text { exchange and creation }\end{array}$ & $\begin{array}{l}\text { - Very close and cooperative relationship } \\
\text { - High levels of commitment and } \\
\text { communication across all hierarchical levels } \\
\text { between the focal firm and initial customer } \\
\text { - Not formalized }\end{array}$ & $\begin{array}{l}\text { - Knowledge exchange \& creation through } \\
\text { primarily tacit-to-tacit mechanisms } \\
\text { (socialization): joint planning and integration } \\
\text { of automated warehouse in the existing } \\
\text { warehouse of the customer }\end{array}$ \\
\hline
\end{tabular}


TABLE 3

Business Model Characteristics and Knowledge Conversion: Business Model Reconfiguration II

Structural Level

\section{Focal Firm $\rightarrow$}

Customers

Focal Firm $\rightarrow$

Distributors

Distributors $\rightarrow$

Customers

Distributors $\rightarrow$ Focal

Firm

\section{Content Level}

- Partial involvement in the interactions with customers (primarily trouble shooting) to support the distributor during the transitory stage of the business model, i.e. partially service defused

- System upgrades, but mediated through distributor

- Support the distributors' activities vis-à-vis the customer

- Facilitate knowledge exchange to the distributor

- 24/7 technical support

- Distributor support tools for sales, installation, and servicing of the system: computer simulation, service portal

- Distributor marketing support: brochures, animations, trade show displays, demonstration material, demonstration system for trade shows, access to

demonstration site

- Training and manuals

- Distributors take the lead on service provision activities aimed at the customer, i.e. partially service infused: installation, planning and integration, spare part delivery, maintenance and repair services,

optimization, trouble shooting, training, etc.

- Marketing, sales and customer relationship management on behalf of the focal firm

\section{Governance Leve}

- Discrete relationship and limited to situations where focal firm helps out the distributor

- Cooperative relationship, but primarily limited to knowledge exchange

- More utilization of contracts as relationship and transaction governance mechanism

- Account management system

- Cooperative relationship, but characterized by utilization of contracts and service level agreements as relationship and transaction governance mechanism

- Cooperative, but primarily limited to knowledge exchange

- More utilization of contracts as relationship
Knowledge Conversion Mechanisms and Capacities

- No particular knowledge exchange or creation

- Knowledge exchange by codification of tacit knowledge in to manuals, trainings and support tools and thus into explicit knowledge (externalization), which is exchanged (explicit-to-explicit) and internalized through its application and goes over into the tacit knowledge base of the distributor (explicit-to-tacit)

- tacit-to-tacit knowledge exchange mechanism (socialization) through engaging the distributor in the resolution of problems (trouble shooting)

- Very limited knowledge creation

- Knowledge exchange through primarily explicit knowledge exchange mechanisms: trainings and manuals

- Very limited knowledge creation

- No particular knowledge exchange or creation other than feedback to focal firm on how to improve the system 
TABLE 4

Business Model Characteristics and Knowledge Conversion Mechanisms: Reconfigured Business Model

\begin{tabular}{|c|c|c|c|}
\hline Structural Level & Content Level & Governance Level & $\begin{array}{c}\text { Knowledge Conversion Mechanisms and } \\
\text { Capacities }\end{array}$ \\
\hline $\begin{array}{l}\text { Focal Firm } \rightarrow \\
\text { Customers }\end{array}$ & $\begin{array}{l}\text { - Fully service defused } \\
\text { - Focal firm only gets involved directly with } \\
\text { the customer in very exceptional cases } \\
\text { - System upgrades, but mediated through } \\
\text { distributor }\end{array}$ & $\begin{array}{l}\text { - No direct relationship between focal firm and } \\
\text { customers }\end{array}$ & $\begin{array}{l}\text { - No particular knowledge exchange or } \\
\text { creation }\end{array}$ \\
\hline $\begin{array}{l}\text { Focal Firm } \rightarrow \\
\text { Distributors }\end{array}$ & $\begin{array}{l}\text { Distributor support tools for sales, } \\
\text { installation, and servicing of the system: } \\
\text { computer simulation, service portal } \\
\text { - Distributor marketing support: brochures, } \\
\text { animations, trade show displays, } \\
\text { demonstration material, demonstration } \\
\text { system for trade shows, access to } \\
\text { demonstration site } \\
\text { - } 24 / 7 \text { technical support } \\
\text { - Training and manuals }\end{array}$ & $\begin{array}{l}\text { - Cooperative relationship, but primarily } \\
\text { limited to knowledge exchange } \\
\text { - Account management system } \\
\text { - Contract as primary relationship and } \\
\text { transaction governance mechanism } \\
\text { - Quality control systems: accreditation } \\
\text { scheme (training control), service portal } \\
\text { (maintenance control) and simulation } \\
\text { (performance and design control) } \\
\text { - Customer registration (cannibalization } \\
\text { control among distributors) }\end{array}$ & $\begin{array}{l}\text { Primarily explicit-to-explicit knowledge } \\
\text { exchange mechanisms (training, manuals, } \\
\text { support tools) } \\
\text { - tacit-to-tacit knowledge exchange } \\
\text { mechanism (socialization) though engaging } \\
\text { the distributor in the resolution of problems } \\
\text { (trouble shooting) } \\
\text { - Very limited knowledge creation }\end{array}$ \\
\hline $\begin{array}{l}\text { Distributors } \rightarrow \\
\text { Customers }\end{array}$ & $\begin{array}{l}\text { - Fully service infused: installation, planning } \\
\text { and integration, spare part delivery, } \\
\text { maintenance and repair services, } \\
\text { optimization, trouble shooting, training, etc. }\end{array}$ & $\begin{array}{l}\text { - Cooperative relationship, but characterized } \\
\text { contract and service level agreement as } \\
\text { primary relationship and transaction } \\
\text { governance mechanism } \\
\text { - Account management system }\end{array}$ & $\begin{array}{l}\text { - Knowledge exchange through primarily } \\
\text { explicit knowledge exchange mechanisms: } \\
\text { trainings and manuals } \\
\text { - Very limited knowledge creation }\end{array}$ \\
\hline $\begin{array}{l}\text { Distributors } \rightarrow \text { Focal } \\
\text { Firm }\end{array}$ & $\begin{array}{l}\text { - Marketing, sales and customer relationship } \\
\text { management on behalf of the focal firm }\end{array}$ & $\begin{array}{l}\text { - Cooperative, but discrete relationship } \\
\text { - Contract as primary relationship and } \\
\text { transaction governance mechanism }\end{array}$ & $\begin{array}{l}\text { No particular knowledge exchange or } \\
\text { creation other than feedback to focal firm on } \\
\text { how to improve the system }\end{array}$ \\
\hline
\end{tabular}


APPENDIX

Example Questions from Interview Guide

\begin{tabular}{|c|c|c|c|}
\hline \multirow[b]{2}{*}{ Phase $^{3}$} & \multicolumn{3}{|c|}{ Interviewees } \\
\hline & Focal Firm & Distributor Firm & Customer Firm \\
\hline $\begin{array}{l}\text { Reconfiguration Phase I - Focal Firm } \\
\text { Service Infusion }\end{array}$ & $\begin{array}{l}\text { - Before the transition, what type of } \\
\text { services were you providing to your } \\
\text { customers and how? } \\
\text { - How did you develop those services? } \\
\text { - What was the role of the distributors at } \\
\text { this point in time regarding service } \\
\text { development and provision? } \\
\text { - What was the role of your customers at } \\
\text { this point in time regarding service } \\
\text { development and provision? }\end{array}$ & $\begin{array}{l}\text { - What involvement did you have with } \\
\text { the focal firm? }\end{array}$ & $\begin{array}{l}\text { - What services did the focal firm } \\
\text { provide you with before the transition } \\
\text { and how? How do you evaluate those } \\
\text { services and their service provision? } \\
\text { - What was your involvement in the } \\
\text { services and service provision? }\end{array}$ \\
\hline $\begin{array}{l}\text { Reconfiguration Phase II - Focal Firm } \\
\text { Service Defusion }\end{array}$ & $\begin{array}{l}\text { - What services do your distributors } \\
\text { provide to their customers (and how), } \\
\text { which you used to provide them } \\
\text { (customers) originally? } \\
\text { - How did you support your distributors } \\
\text { during the transition process? } \\
\text { - How did the customers reaction to this } \\
\text { new situation? Did they comply with } \\
\text { this new service provision structure? } \\
\text { - Are there any services left that you } \\
\text { have to provide to the customers } \\
\text { directly and how? }\end{array}$ & $\begin{array}{l}\text { - How did the focal firm support you } \\
\text { with building the competences to take } \\
\text { over the service provision? } \\
\text { - Did you develop any new services that } \\
\text { were not provided by the focal firm } \\
\text { before? What was the involvement of } \\
\text { the focal firm? }\end{array}$ & $\begin{array}{l}\text { - How did the services and their } \\
\text { provision change over time? What was } \\
\text { your involvement in the transition? } \\
\text { - How did the transition effect your } \\
\text { business? } \\
\text { How did the transition affect your } \\
\text { relationship with the focal firm and } \\
\text { your distributor? }\end{array}$ \\
\hline
\end{tabular}

\footnotetext{
${ }^{3}$ Phases and descriptors became only apparent after the analysis of the data and are used in this table only for structuring purposes.
} 
Reconfigured Business Model
- What services are you providing to your distributors on a regular basis and how? How did you develop them and what was the involvement of your distributors?

- What services do your distributors provide to their customers on a regular basis and how? How did your

distributors develop them and what was the involvement of your firm?

- How do you support your distributors in the delivery of services to their customer?

- Are there any services still delivered to the customer by you and how?

- How do you maintain control over your distributors' activities and performance?

- How do the contractual agreements specify each party's role in the service provision?
- What services do you provide to your customers on a regular basis and how? How did you develop them and what was the involvement of the focal firm?

- What services does the focal firm provide to your customers on a regular basis and how? What is your involvement?

- How does the focal firm support you in your service provision?

- How would you characterize the relationship between your firm and the focal firm and your customers?

- How would you characterize the relationship between your customers and the focal firm?

- How do the contractual agreements specify each party's role in the service provision?
- What services does the focal firm provide you on a regular basis? What is the involvement of your distributor? What is your involvement? How do you evaluate the service and the service provision?

- What services does your distributor provide you on regular basis? What is the involvement of the focal firm? What is your involvement? How do you evaluate the service and the service provision?

- How would you characterize the relationship between your firm and the focal firm and your distributor firm?

- How would you characterize the relationship between the focal firm and your distributor?

- How do the contractual agreements specify each party's role in the service provision? 